\title{
Elaboration of New Modified Electrodes (MEs) by Electropolymerization of Cu(II)-Schiff Base Complexes Bearing Pyrrole Moieties: Application in Electroreduction of Acetophenone and Carbon Dioxide
}

Ahcene Ait Amer ${ }^{1,2,3^{*}}$, Hocine Ilikti ${ }^{1}$, Christophe Beyens ${ }^{3}$, Joël Lyskawa ${ }^{3}$, and Ulrich Maschke ${ }^{3}$

${ }^{1}$ Laboratoire de Chimie et d'Electrochimie des Complexes Métalliques (LCECM), Université des Sciences et de la Technologie d'Oran Mohamed Boudiaf (USTO-MB), BP 1505, El-M'naouer, 31000 Oran, Algeria

${ }^{2}$ Département de Chimie, Faculté des Sciences Exactes, Université Djilali Liabès (UDL), BP 89, 22000 Sidi-Bel-Abbès, Algeria

\footnotetext{
${ }^{3}$ Unité Matériaux et Transformations - UMET (UMR CNRS Nº8207), Bâtiment C6, Université Lille 1- Sciences et Technologies, 59655 Villeneuve d'Ascq Cedex, France
}

E-mail : ahceneaitamer5@gmail.com; ahcene.aitamer@univ-usto.dz 


\begin{abstract}
Novel functional Schiff base ligands bearing pyrrole moieties in their structures, L1:1-(3Pyrrole-1-yl-propylimino-methyl)-naphtalen-2-ol, L2:1-(3-Pyrrole-1-yl-propylimino-methyl)phenol and L3: 1-(3-Pyrrole-1-yl-phenylimino-methyl)-naphtalen-2-ol as well as their $\mathrm{Cu}(\mathrm{II})$ complexes, have been synthesized and characterized by means of common spectroscopic analysis methods such as FTIR, UV-Vis, ${ }^{1} \mathrm{H}$ NMR, ${ }^{13} \mathrm{C}$ NMR, GC-MS and thermogravimetric analysis (TGA). The complexes, along with their metallic centres, were electropolymerized by the cyclic voltammetry method on platinum (Pt) and indium tin oxide (ITO) substrates, so that new and original modified electrodes (MEs) could be obtained, i.e. $\mathrm{ME} \operatorname{Poly}\left(\mathrm{L}_{\mathrm{i}}-\mathrm{Cu}\right) \mathrm{Pt}$ and ME Poly $\left(\mathrm{L}_{\mathrm{i}}-\mathrm{Cu}\right) \mathrm{ITO}(\mathrm{i}=1-3)$. MEs obtained on ITO were characterized by FTIR spectroscopy and their morphology was investigated using scanning electron microscopy (SEM) and elemental composition by EDX analysis. The catalytic activity of these modified electrodes was successfully evaluated using electroreduction reactions in aqueous media of organic substrates. The efficiently of acetophenone reduction was significantly improved by increasing the quantity of added substrate. The value of cathodic current intensity ipc goes up from 7 to $42 \mu \mathrm{A}$ for substrate volume values varying from 0 to $40 \mu \mathrm{L}$, respectively. In addition, a significant increase of current values from $-70 \mu \mathrm{A}$ to $175 \mu \mathrm{A}$ was observed in the presence of a saturated solution of $\mathrm{CO}_{2}$.
\end{abstract}

Keywords Modified electrodes (MEs); Schiff bases; N-pyrrole ligands; Spectroscopy analysis; Electropolymerization; Catalytic activity. 


\section{Introduction}

For many years, Schiff bases have been successfully used in coordination chemistry as ligands due to their simple synthesis and their wide range of chelating ability with several metal ions [1]. Nowadays, many of these Schiff bases and their transition metal complexes are successfully employed in a large number of applications. Indeed, they can be used in biological activities [2-3], as well as in sensors [4-5], energy storage devices, solar cells [6] and even in corrosion protection processes [7]. The Schiff base complexes have been investigated using electrochemical redox reactions, and they were proved to be very efficient in the fields of electrocatalysis [8-9] and catalysis for a large number of reactions [10].

On the other hand, the chemical modification of electrodes has become a rapidly growing area of research because of its importance in various domains, such as electro- and photo-catalysis, electro-synthesis, electro-analysis and molecular devices [11-15]. Chronologically, the concept of the modified electrode (ME) has attracted the attention of many researchers as soon as the first prototypes were produced by chemical modification of the metal surfaces. However, the first obtained electrodes were not very effective [16-17]. During the 1970s, the discovery of new conductive polymers, such as polypyrrole, polythiophene and polyaniline, was beneficial since it helped to develop some MEs by doping the aforementioned polymers, although their effectiveness was limited [18-20]. Later, other functional and polymerizable molecules were synthesized. These molecules have the ability to form organometallic complexes with transition metal ions, such as poly-M-phtalocyanines, porphyrines, polypyridyl metal complexes and tetraazamacrocycles [21-23]. These materials exhibit enhanced electrocatalytic activity for oxidation and reduction of various organic substrates as well as for the reduction of $\mathrm{CO}_{2}$.

Polymer coatings have been used to deposit metal complexes on electrode surfaces. The redox polymer MEs have been employed in the catalysis of electrochemical reactions [24-33]. 
Among the complexes used one can mention those derived from Schiff bases ligands which are generally electropolymerized on various metal electrodes. Dahm and Peters [34] studied the catalytic reduction of halides on carbon electrodes modified with $\mathrm{Ni}$ (II) - salen complex. Other research studies were also conducted on poly (Metal-salen) [35]. However, the studies were more interesting when the metal complexes include pyrrole units. These materials were obtained by direct anodic oxidation of pyrrole moieties to yield good modified polymer electrodes. It should be noted that the ligand architecture plays a significant role in the synthesis of this kind of materials.

Only a few studies related to copper complexes of poly ( $\mathrm{N}$-alkyl pyrrole), containing Schiff bases, have been reported in literature so far such as electrochemical and spectroelectrochemical properties of copper (II) and Schiff-base complexes of 2-(3-pyrrole-1yl-propylimino-methyl) phenol [36], or the synthesis and characterization of 6-[3'-N-pyrrole propoxy]-2-hydroxyacetophenone combined with 1,2-diaminoethane, which corresponds to a derivative of $\mathrm{N}$-substituted pyrrole salicylaldehyde, along with their copper complexes [3738]. For all these reasons, three new ligands were successfully synthesized and characterized, along with their cooper (II) complexes that are based on Schiff bases bearing N-pyrrole unities in their structures. The electropolymerization of these monomers was achieved by cyclic voltammetry on platinum (Pt) and Indium tin oxide (ITO) supports to obtain new electrodes modified with polymer complexes. The polymer films on electrodes were characterized using techniques such as FTIR, SEM, and EDX. In addition, the catalytic activity was also successfully investigated in order to reduce both acetophenone and carbon dioxide on MEs obtained in the present study. 


\section{Experimental}

\subsection{Materials}

Ethanol was purchased from Merck (absolute grade for analysis); hexane, acetone, diethyl ether and petroleum ether were purchased from Aldrich (p.a. grade solvents). Magnesium sulphate, sodium hydroxide, sodium chloride, Lithium aluminium hydride $\left(\mathrm{LiAlH}_{4}\right)$, copper acetate, N-(2-cyanoethyl) pyrrole (NCPy), 2-hydroxy-1-naphtaldehyde, salicylaldehyde and 1-(2-aminophenyl) pyrrole were obtained from Sigma Aldrich. All these reagents were used as received.

\subsection{Methods}

FTIR spectra were recorded in ATR mode using a Perkin Elmer Frontier model spectrometer between $4000 \mathrm{~cm}^{-1}$ and $600 \mathrm{~cm}^{-1}$ with a spectral resolution of $4 \mathrm{~cm}^{-1}$ over 16 scans. Electronic spectra (UV-Vis) were obtained on a Varian Cary 100 UV-visible spectrophotometer, using Hellma Quartz cells (100-QS) exhibiting 10mm thickness.

${ }^{1} \mathrm{H}$ - and ${ }^{13} \mathrm{C}-\mathrm{NMR}$ spectra were recorded in appropriate deuterated solvents (concentration $6 \mathrm{mg} / 10 \mathrm{~mL}$ ) with tetramethylsilane as internal standard, using a Bruker AC $300 \mathrm{MHz}$ spectrometer. The Gas Chromatography/Mass Spectrometry (GC/MS) analysis was performed on a Perkin Elmer Clarus 680 gas chromatograph coupled with a Clarus 600T mass detector (PerkinElmer, Shelton, USA).

A Perkin Elmer Pyris1 thermogravimetric analyzer was used for recording thermogravimetric data of the ligands and complexes in a nitrogen atmosphere $(20 \mathrm{~mL} / \mathrm{min})$, applying a heating rate of $10^{\circ} \mathrm{C} / \mathrm{min}$.

The electrochemical experiments were carried out using Autolab (PGSTAT) potentiostat controlled by GPES software (version 4.9.005). Cyclic voltammograms were recorded using $5 \mathrm{ml}$ conventional cell with three electrode system. Working electrodes are disc platinum 
(Metrohm) with diameter $3 \mathrm{~mm}$ were polished with diamond past and rinsed with acetone and acétonitrile before using, and ITO-glass electrode with $100 \mathrm{~nm}$ thickness and $50 \Omega$ as resistance were prepared in suitable size (electroactive area $1 \mathrm{~cm}^{2}$ ) with counter electrode in platinum wire. All potentials are expressed versus the saturated $\mathrm{Ag} / \mathrm{AgCl}$ electrode saturated with $\mathrm{KCl}$. Nitrogen gas (pre-saturated with solvent) was bubbled vigorously the solution for 20min to ensure saturation (concerning the experiments conducted with $\mathrm{CO}_{2}$, bubbling was carried out until saturation, and the $\mathrm{pH}$ value of the medium reached 3.5). Tetrabutylammonium hexafluorophosphate $\left(\mathrm{TBAPF}_{6}\right)$ and Tetrabutylammonium perchlorate $\left(\mathrm{TBAClO}_{4}\right)\left(\right.$ Aldrich) were dried under vacuum at $100^{\circ} \mathrm{C}$ before use. Acetonitrile and DMF were dried over appropriate agents and distilled prior to use.

\subsection{Synthesis of compounds}

In general, the monomers were synthesized by reproducing the same synthesis protocol with appropriate aldehydes and amines. In the following the synthesis method of monomer L1 will be given, which represents the synthetic pathway of the other monomers as well. Their structures were also represented in Fig. 1.

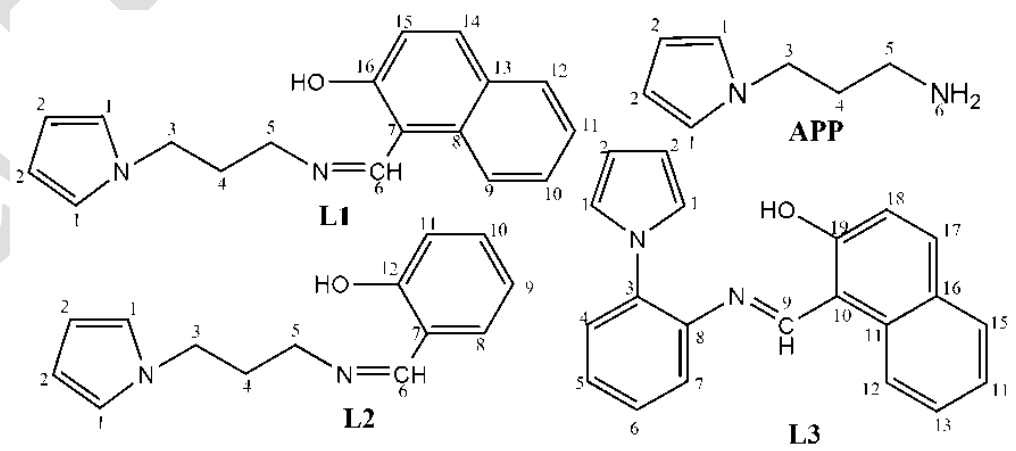

Fig. 1: Structures of 1-(2-aminophenyle) pyrrole (APP) and ligands L1, L2, and L3. 


\subsubsection{Synthesis of 1-(3-aminopropyl) pyrrole}

1-(3-aminopropyl) pyrrole (APP) was prepared by reduction of 1-(2-cyanoethyl)-pyrrole with $\mathrm{LiAlH}_{4}$ in dry diethyl ether as reported in literature [39].

The product appearance: light-yellow viscous oil, yield: $78.4 \%$, refractive index: $\mathrm{n}_{\mathrm{D}\left(20^{\circ} \mathrm{C}\right)}=1.5217$

FTIR (ATR) v (cm $\left.{ }^{-1}\right): 3369-3292\left(\mathrm{NH}_{2}\right), 3090$ (aromatic C-H stretch), 2950 and 2870 (aliphatic C-H stretch), 1503 (N-H out of plane deformation), 1300 (N-ring stretch), 1280 (C$\mathrm{N}$ stretch) and 750 (C-H out of plane).

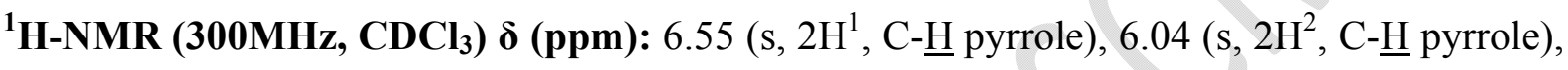
$3.87\left(\mathrm{t},{ }^{3} \mathrm{~J}=6.94 \mathrm{~Hz}, 2 \mathrm{H}^{3}, \underline{\mathrm{C}}_{2}\right), 2.60 \mathrm{ppm}\left(\mathrm{t},{ }^{3} \mathrm{~J}=6.84 \mathrm{~Hz}, 2 \mathrm{H}^{5}, \mathrm{C}_{2}\right), 1.80\left(\mathrm{p},{ }^{3} \mathrm{~J}=6.88 \mathrm{~Hz}, 2 \mathrm{H}^{4}\right.$, $\left.\mathrm{C}_{2}\right), 1.22\left(\mathrm{~s}, 2 \mathrm{H}, \underline{\mathrm{N}}_{2}\right)$.

${ }^{13}$ C-NMR (75MHz, $\left.\mathbf{C D C l}_{3}\right) \boldsymbol{\delta}$ (ppm): 120.53 (C', pyrrole), $108.06\left(\mathrm{C}^{2}\right.$, pyrrole) and 47.35 $\left(C^{3}\right), 39.07\left(C^{5}\right), 34.53\left(C^{4}\right)$ aliphatic $\underline{C H}_{2}$ carbons.

MS (ES $\left.{ }^{+}\right): 124\left(\mathrm{M}^{+}\right), 81\left(\mathrm{C}_{5} \mathrm{H}_{6} \mathrm{~N}^{+}\right.$, base peak). Accurate mass $\left(\mathrm{ES}^{+}\right)$: 124.145 , calculated: 124.184.

\subsubsection{Synthesis of 1-(3-Pyrrole-1-yl-propylimino-methyl)-naphtalen-2-ol (L1)}

In a three-necked flask $10 \mathrm{mmol}(1.72 \mathrm{~g})$ of 2-hydroxy-1-naphtaldehyde were dissolved in $15 \mathrm{~mL}$ of absolute ethanol under thermal agitation, and $10 \mathrm{mmol}(1.24 \mathrm{~g})$ of APP was added using the same volume of absolute ethanol. The mixture was then kept under nitrogen atmosphere and heated under reflux $\left(\sim 78^{\circ} \mathrm{C}\right)$ for $3 \mathrm{~h}$. After cooling, the solvent was removed with a rotary evaporator and the crude product was purified by column chromatography using a mixture of petroleum ether-acetone $(3: 1)$ as eluent, revealing high purity of the compound. The product appearance: brown viscous oil, yield: $82.1 \%$. 
FTIR (ATR) v (cm $\left.{ }^{-1}\right): 3300$ (broad, OH aromatic), 3097 and 3055 (aromatic C-H stretch), 2965 and 2870 (aliphatic C-H stretch), $1630(\mathrm{C}=\mathrm{N}), 1550,1525$ and 1490 (aromatic C-C stretch), 1357 (C-N stretch), 1270 (=C-OH phenolic), 825 and 720 (C-H out of plane).

${ }^{1} \mathrm{H}-\mathrm{NMR}\left(300 \mathrm{MHz}, \mathbf{C D}_{3} \mathrm{OD}\right) \boldsymbol{\delta}$ (ppm): 10.89 (s, $1 \mathrm{H}, \mathrm{OH}^{16}$ phenolic), 8.89 (s, 1H, $\mathrm{H}^{6}$, $\underline{\mathrm{HC}}=\mathrm{N}), 7.99\left(\mathrm{~d}, J=8.32 \mathrm{~Hz}, 1 \mathrm{H}, \mathrm{H}^{14}\right.$ aromatic), $7.77\left(\mathrm{~d}, J=8.32 \mathrm{~Hz}, 1 \mathrm{H}, \mathrm{H}^{9}\right.$ aromatic), $7.62(\mathrm{~m}$, $1 \mathrm{H}, \mathrm{H}^{12}$ aromatic), $7.46\left(\mathrm{ddd}, J=8.41,7.04,1.47 \mathrm{~Hz}, 1 \mathrm{H}, \mathrm{H}^{10}\right.$ aromatic), $7.24\left(\mathrm{~m}, 1 \mathrm{H}, \mathrm{H}^{11}\right.$ aromatic), $6.82\left(\mathrm{~d}, J=9.38 \mathrm{~Hz}, 1 \mathrm{H}, \mathrm{H}^{15}\right.$ aromatic), $6.75\left(\mathrm{~s}, 2 \mathrm{H}^{1}, \mathrm{C}-\underline{\mathrm{H}}\right.$ pyrrole $), 6.12\left(\mathrm{~s}, 2 \mathrm{H}^{2}, \mathrm{C}-\underline{\mathrm{H}}\right.$ pyrrole), 4.09 (t, $\left.J=6.70 \mathrm{~Hz}, 2 \mathrm{H}^{3}, \mathrm{CH}_{2}\right), 3.60$ (t, $\left.J=6.77 \mathrm{~Hz}, 2 \mathrm{H}^{5}, \mathrm{C}_{2}\right), 2.24$ (p, J=6.76Hz, $2 \mathrm{H}^{4}$, $\left.\mathrm{C}_{2}\right)$.

${ }^{13}$ C-NMR (75 MHz, CD 3 OD) $\delta$ (ppm): $180.68\left(\mathrm{C}^{16}, \underline{\mathrm{C}}-\mathrm{OH}\right.$ phenolic), $160.66\left(\mathrm{C}^{6}, \underline{\mathrm{C}}=\mathrm{N}\right)$, 139.84( $\left(\mathrm{C}^{14}\right), \quad 135.82\left(\mathrm{C}^{8}\right), \quad 130.18\left(\mathrm{C}^{10}\right), 129.44\left(\mathrm{C}^{12}\right), 127.32\left(\mathrm{C}^{13}\right), 126.19\left(\mathrm{C}^{11}\right), 123.84\left(\mathrm{C}^{10}\right)$, 119.37 $\left(\mathrm{C}^{15}\right), 109.84\left(\mathrm{C}^{7}\right)$, all aromatic carbons, $121.52\left(\mathrm{C}^{1}\right.$, pyrrole $), 109.17\left(\mathrm{C}^{2}\right.$, pyrrole $)$, and $58.35\left(\mathrm{C}^{3}\right), 47.14\left(\mathrm{C}^{5}\right), 33.13\left(\mathrm{C}^{4}\right)$ aliphatic $\underline{\mathrm{CH}}_{2}$ carbons.

MS (ES $\left.{ }^{+}\right): 278\left(\mathrm{M}^{+}\right), 198.241\left(\mathrm{C}_{13} \mathrm{H}_{12} \mathrm{NO}^{+}\right.$, base peak). Accurate mass $\left(\mathrm{ES}^{+}\right)$: 278.222, calculated: 278.142 .

\subsubsection{Synthesis of 1-(3-Pyrrole-1-yl-propylimino-methyl)-phenol (L2)}

1-(3-Pyrrole-1-yl-propylimino-methyl)-phenol (L2) was prepared in the same manner as L1, with $10 \mathrm{mmol}(1.22 \mathrm{~g})$ of salicylaldehyde and an equivalent of 1-(3-aminopropyl) pyrrole (1.24g). The product appearance: dark orange viscous oil, yield: $78.8 \%$.

IRTF (ATR) v (cm $\left.{ }^{-1}\right): 3350$ ( $\mathrm{vOH}$ aromatic), 3098 and 3060 (vC-H aromatic), 2930 and 2875 (vC-H aliphatic $\left.\underline{\mathrm{CH}}_{2}\right), 1626(\mathrm{C}=\mathrm{N}), 1583,1501$ and $1465(\mathrm{vC}=\mathrm{C}$ aromatic), $1278(\mathrm{vC}-\mathrm{N})$, 1109 (=들 phenolic), 750 and 720 ( $\delta \mathrm{C}-\mathrm{H}$ out of plane).

${ }^{1} \mathrm{H}-\mathrm{NMR}$ (300 MHz, CD $\mathbf{3}$ OD) $\boldsymbol{\delta}$ (ppm):10.00 (s, 1H, $\underline{\mathrm{H}}^{12}$ phenolic), 8.29 (s, 1H, $\mathrm{H}^{6}$, $\underline{\mathrm{HC}}=\mathrm{N}), 7.32\left(\mathrm{dd}, J=2.51,6.70 \mathrm{~Hz}, 1 \mathrm{H}, \mathrm{H}^{7}\right.$ aromatic $), 7.28\left(\mathrm{dd}, J=3.55,7.50 \mathrm{~Hz}, 1 \mathrm{H}, \mathrm{H}^{9}\right.$ 
aromatic), $6.89\left(\mathrm{~m}, 1 \mathrm{H}, \mathrm{H}^{8}\right.$ aromatic), $6.84\left(\mathrm{~m}, 1 \mathrm{H}, \mathrm{H}^{11}\right.$ aromatic), $6.66\left(\mathrm{~s}, 2 \mathrm{H}^{1}, \mathrm{C}-\underline{\mathrm{H}}\right.$ pyrrole), $6.08\left(\mathrm{~s}, 2 \mathrm{H}^{2}, \mathrm{C}-\underline{\mathrm{H}}\right.$ pyrrole), $3.96\left(\mathrm{t}, J=6.80 \mathrm{~Hz}, 2 \mathrm{H}, \mathrm{H}^{3}, \mathrm{C}_{2}\right), 3.47\left(\mathrm{t}, J=7.32 \mathrm{~Hz}, 2 \mathrm{H}, \mathrm{H}^{5}\right.$, $\left.\mathrm{C}_{2}\right), 2.08\left(\mathrm{p}, J=6.78 \mathrm{~Hz}, 2 \mathrm{H}, \mathrm{H}^{4}, \underline{\mathrm{CH}}_{2}\right)$.

${ }^{13}$ C-NMR (75 MHz, CD 3 OD) $\delta$ (ppm): $167.43\left(\mathrm{C}^{6}, \underline{\mathrm{C}}=\mathrm{N}\right), 138.71\left(\mathrm{C}^{12}, \underline{\mathrm{C}}-\mathrm{OH}\right.$ phenolic), $133.92\left(\mathrm{C}^{10}\right), 132.7\left(\mathrm{C}^{8}\right), 121.69\left(\mathrm{C}^{07}\right), 118.17\left(\mathrm{C}^{9}\right), 116\left(\mathrm{C}^{11}\right)$, all aromatic carbons, 119.13 $\left(\mathrm{C}^{1}\right.$, pyrrole), $109.39\left(\mathrm{C}^{2}\right.$, pyrrole) et $55.90\left(\mathrm{C}^{3}\right), 33.93\left(\mathrm{C}^{5}\right), 18.37\left(\mathrm{C}^{4}\right)$ aliphatic $\underline{\mathrm{CH}}_{2}$ carbons MS (ES $\left.{ }^{+}\right): 228\left(\mathrm{M}^{+}\right), 148.141\left(\mathrm{C}_{9} \mathrm{H}_{10} \mathrm{NO}^{+}\right.$, base peak). Accurate mass $\left(\mathrm{ES}^{+}\right)$: 228.138 , calculated: 228,126 .

\subsubsection{Synthesis of 1-(3-Pyrrole-1-yl-phenylimino-methyl)-naphtalen-2-ol (L3)}

1-(3-Pyrrole-1-yl-phenylimino-methyl)-naphtalen-2-ol (L3) was prepared in the same manner as L1, with $3.1 \mathrm{mmol}(0.53 \mathrm{~g})$ of 2-hydroxy-1-naphtaldehyde and an equivalent of 1-(2aminophenyl) pyrrole $(0.5 \mathrm{~g})$. The solvent used in this reaction was methanol. At the end of the reaction and after cooling, the precipitated product was filtered and washed with cold ethanol, and finally dried in vacuum.

The product appearance: white-yellow solid; yield: $48.5 \% ; \mathrm{m}_{\mathrm{p}}=193^{\circ} \mathrm{C}$ (determined by DSC).

FTIR (ATR) v (cm $\left.{ }^{-1}\right): 3360$ (broad, OH aromatic), 3064 (aromatic C-H stretch), $1625(\mathrm{C}=\mathrm{N})$, 1510, 1463 and 1420 (aromatic C-C stretch), 1310 (C-N stretch), 1240 (=C-OH phenolic), 812 and 742 (C-H out of plane).

${ }^{1}$ H-NMR (300 MHz, acetone-D $)$ 反 (ppm): $9.76\left(\mathrm{~s}, 1 \mathrm{H}, \mathrm{H}^{9}, \underline{\mathrm{HC}}=\mathrm{N}\right), 8.09(\mathrm{~d}, J=8.6 \mathrm{~Hz}, 1 \mathrm{H}$, $\mathrm{H}^{12}$ aromatic), $7.86\left(\mathrm{~d}, J=8.50 \mathrm{~Hz}, 2 \mathrm{H}, \mathrm{H}^{4,15}\right.$ aromatic), $7.61\left(\mathrm{~d}, J=7.70 \mathrm{~Hz}, 1 \mathrm{H}, \mathrm{H}^{13}\right.$ aromatic), 7.44-7.34 (m, 3H, $\mathrm{H}^{14,15,7}$ aromatic), 7.19-6.99 (m, 4H, 2C- $\underline{\mathrm{H}}^{2}$ pyrrole, $\mathrm{H}^{17,6}$ aromatic), 6.56 (m, 2H, C- $\underline{\mathrm{H}}^{2}$ pyrrole $\left.2 \mathrm{H}\right), 5.28\left(\mathrm{~s}, 1 \mathrm{H}, \underline{\mathrm{O}}^{19}\right)$.

${ }^{13}$ C-NMR (75 MHz, acetone-D $) \delta$ (ppm): $157.68\left(\mathrm{C}^{9}, \underline{\mathrm{C}}=\mathrm{N}\right), 140.16\left(\mathrm{C}^{19}, \underline{\mathrm{C}}-\mathrm{OH}\right.$ phenolic), 138.52 $\left(\mathrm{C}^{8}\right), \quad 134.78\left(\mathrm{C}^{17}\right), \quad 130.67\left(\mathrm{C}^{3}\right), \quad 130.65\left(\mathrm{C}^{16}\right), \quad 129.76\left(\mathrm{C}^{11}\right), \quad 19.51\left(\mathrm{C}^{10}\right), \quad 128.36\left(\mathrm{C}^{7}\right)$, 
$128.15\left(\mathrm{C}^{15}\right), \quad 127.95\left(\mathrm{C}^{12}\right), \quad 125.57\left(\mathrm{C}^{13}\right), \quad 124.81\left(\mathrm{C}^{14}\right), \quad 123.19\left(\mathrm{C}^{6}\right), \quad 122.66\left(\mathrm{C}^{1}, \quad\right.$ pyrrole $)$, 120.86(C $\left.C^{5}\right), 118.98\left(C^{18}\right), 117.44\left(C^{4}\right), 110.13\left(C^{2}\right.$, pyrrole $)$.

MS (ES $\left.)^{+}\right): 312\left(\mathrm{M}^{+}\right), 311.230\left(\mathrm{C}_{31} \mathrm{H}_{15} \mathrm{~N}_{2} \mathrm{O}^{+}\right.$, base peak). Accurate mass $\left(\mathrm{ES}^{+}\right): 312.255$, calculated: 312.365 .

\subsubsection{Synthesis of the complexes}

The copper complexes ( $\mathrm{L} 1-\mathrm{Cu}, \mathrm{L} 2-\mathrm{Cu}$ and $\mathrm{L} 3-\mathrm{Cu})$ were prepared as follows: A warm solution of $\mathrm{Cu}\left(\mathrm{CH}_{3} \mathrm{COO}\right)_{2}(0.008 \mathrm{~mol})$ in $15 \mathrm{~mL}$ of methanol was added to an absolute ethanol solution $(15 \mathrm{~mL})$ of desired ligand $(0.016 \mathrm{~mol})$ and the mixture was stirred at refluxed temperature for 1h. The mixture was cooled in an ice bath for $2 \mathrm{~h}$ and then kept at room temperature for $24 \mathrm{~h}$ until precipitation of the solid product, which was filtered, washed with anhydrous cold ethanol, and finally dried in vacuum. 


\section{Results and Discussion}

\subsection{Electronic spectra}

Table 1 illustrates some spectroscopic data of L1, L2 and L3 from UV-visible spectroscopy analysis in methanol at room temperature. In general, the bands observed in the range from 225 to $320 \mathrm{~nm}$ can be assigned to the low energy transition of $\pi \rightarrow \pi^{*}$ aromatic rings. The band beyond $330 \mathrm{~nm}$ can be attributed to the $\mathrm{n} \rightarrow \pi^{*}$ transition (excitation of electrons of the azomethine group).

\section{Electronic data}

$\lambda_{\text {nm }}\left(\varepsilon\right.$, mole $\left.^{-1} . \mathrm{cm}^{-1}\right)$ Solvent : methanol, room temperature

\begin{tabular}{ccc}
\hline L1 & L2 & L3 \\
$235(44973)$ & $225(18810)$ & $234(65217)$ \\
$306(15661)$ & $254(16398)$ & $266(19304)$ \\
$331(08783)$ & $315(05205)$ & $290(14261)$ \\
$401(16613)$ & $410(01125)$ & $307(12000)$ \\
$417(17121)$ & & $332(08174)$ \\
\hline
\end{tabular}

Table 1: UV-Visible spectroscopic data of L1, L2 and L3 ligands.

The Ar-OH band has an acid character because of the high resonance (delocalized $\pi$-electron system), and can easily establish intermolecular hydrogen bonding with the azomethine groups. The formation of keto-enol equilibrium is thus expressed in all media by the dual band in the range from 395 to $435 \mathrm{~nm}$ (Fig. 2), for L2 it can be estimated that there is ketoenolic equilibrium due to the presence of the band at $410 \mathrm{~nm}$ with predomination of enolic 
form $($ A ketone/ A enol $=0.216)$. Absorption bands represent maxima at 401 and $417 \mathrm{~nm}$ for ligand L1 with an important $\varepsilon$ (17121), which is explained by tautomeric phenol-quinone equilibrium valid in different solvents (A quinole/ $\mathrm{A}$ enol $=1.030)$.

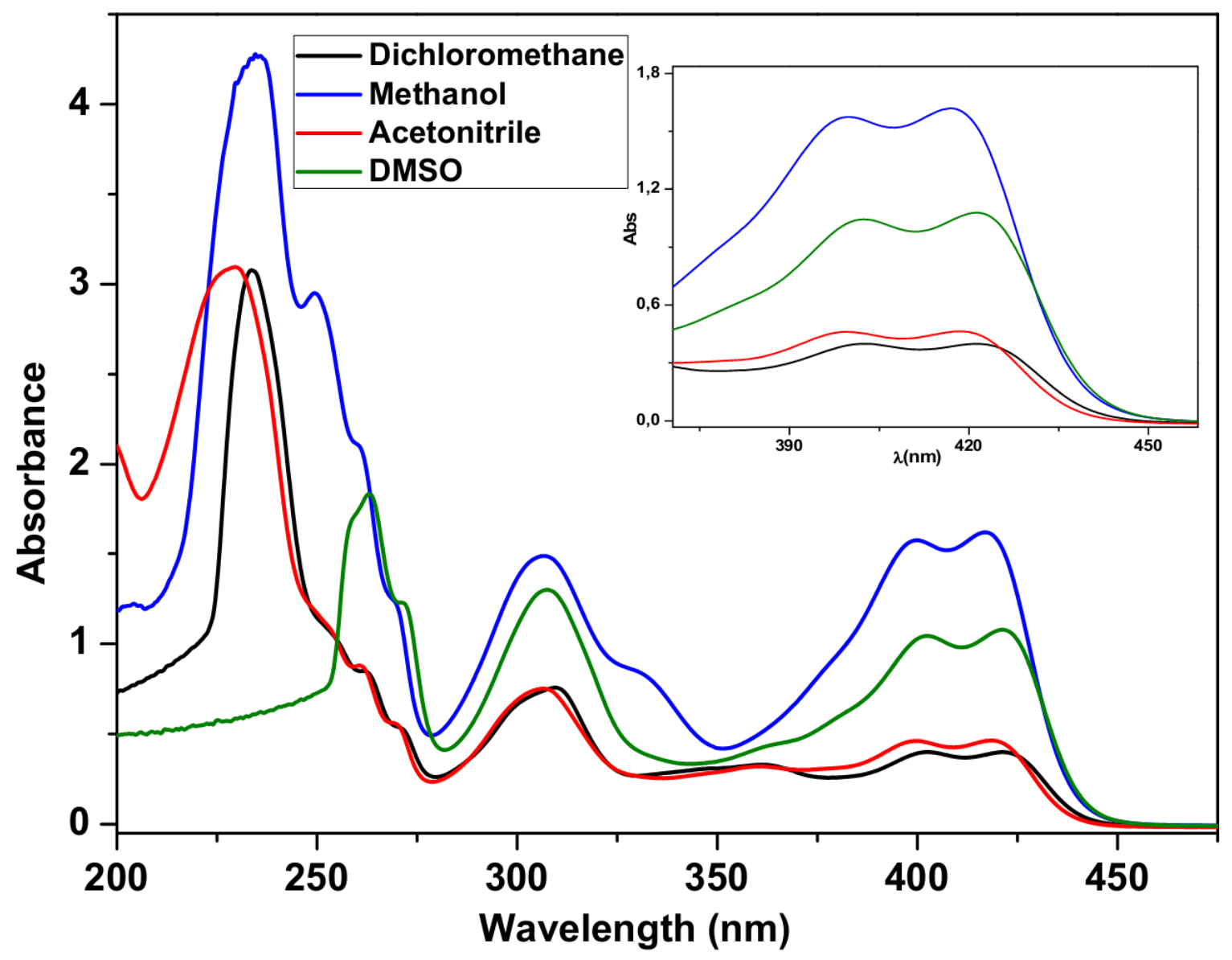

Fig. 2: Electronic spectra of L1 in different solvents.

The electronic absorption spectra of the three copper (II) Schiff base complexes in the UVvisible region were measured in $\mathrm{CH}_{2} \mathrm{Cl}_{2}$, THF, and DMSO. The spectra were found to be rather similar; in general intense transitions between $240-330 \mathrm{~nm}$ can be associated to intraligand transitions $\pi-\pi^{*}$, and in the range of $360-400 \mathrm{~nm}, \mathrm{n}-\pi^{*}$ transitions of the Schiff bases can be observed. The wavelength values recorded for the complexes (Table 2) are shifted compared to the values obtained for the ligands, due to the coordination effect. Indeed, 
Metal-ligand charge transfer (MLCT) transitions accompanied with low intensities of wavelength maxima at 622,584 and $643 \mathrm{~nm}$ in $\mathrm{CH}_{2} \mathrm{Cl}_{2}$, (similar behavior for other solvents) were attributed to $\mathrm{d} \rightarrow \mathrm{d}$ transitions for $\mathrm{L} 1-\mathrm{Cu}, \mathrm{L} 2-\mathrm{Cu}$, and $\mathrm{L} 3-\mathrm{Cu}$, respectively [40-42]. The UV-visible absorption bands confirm the complexation of different ligands with the metal ion.

\section{Electronic data}

Complexes

$\lambda_{\max }(\mathbf{n m})$

\begin{tabular}{ccc}
\hline $\mathbf{C H}_{\mathbf{2}} \mathbf{C l}_{\mathbf{2}}$ & THF & DMSO \\
$239(1.48), 316(0.78)$, & $221(2.05), 293(0.49)$, & $263(1.51), 311(0.94)$, \\
$381(0.34), 400(0.31)$, & $306(0.30), 405(0.031)$, & $382(0.45), 401(0.40)$, \\
$622(0.106)$ & $641(0.117)$ & $603(0.205)$
\end{tabular}
[L2-Cu] 242(2.60), 272(1.35), $302 \quad$ 227(2.60), 270(0.71), $\quad$ 270(1.21), 302(1.48),
(0.61), 365(0.55), $\quad 305(0.45), 360(0.30), \quad 362(1.48), 580(0.216)$
$584(0.062) \quad 570(0.210)$
[L3-Cu] 255(1.41), 327(0.93), 387(0.38), 406(0.33), 311(1.13), 377(0.89), 265(0.86), 309(0.66), 643(0.088) 394(0.85), 438(0.38), $606(0.165)$ 376(0.32), 397(0.28), $652(0.126)$

Table 2: UV-Visible data recorded for $\mathrm{L} 1-\mathrm{Cu}, \mathrm{L} 2-\mathrm{Cu}$ and $\mathrm{L} 3-\mathrm{Cu}$.

\subsection{FTIR spectra}

FTIR spectra of ligands L1, L2 and L3, show strong sharp bands at 1630, 1626 and $1625 \mathrm{~cm}^{-1}$, respectively, which are characteristic for $\mathrm{C}=\mathrm{N}$ stretching vibrations. The broad absorption band at $3200-3500 \mathrm{~cm}^{-1}$ corresponds to the hydrogen bonded hydroxyl stretching vibration. Upon complexation, the azomethine group $(\mathrm{C}=\mathrm{N})$ stretching band undergoes a negative shift of 7 to $15 \mathrm{~cm}^{-1}$ (Fig. 3 and Table 3); which may be attributed to the coordination of the nitrogen atom of the imine group to the metal center $\left(\mathrm{Cu}^{2+}\right)$. The formation of the $\mathrm{M}-\mathrm{N}$ bond 
(metal-nitrogen) is confirmed by the appearance of the $v(\mathrm{MN})$ bands in the $620-650 \mathrm{~cm}^{-1}$ region in agreement with the literature [43-44].

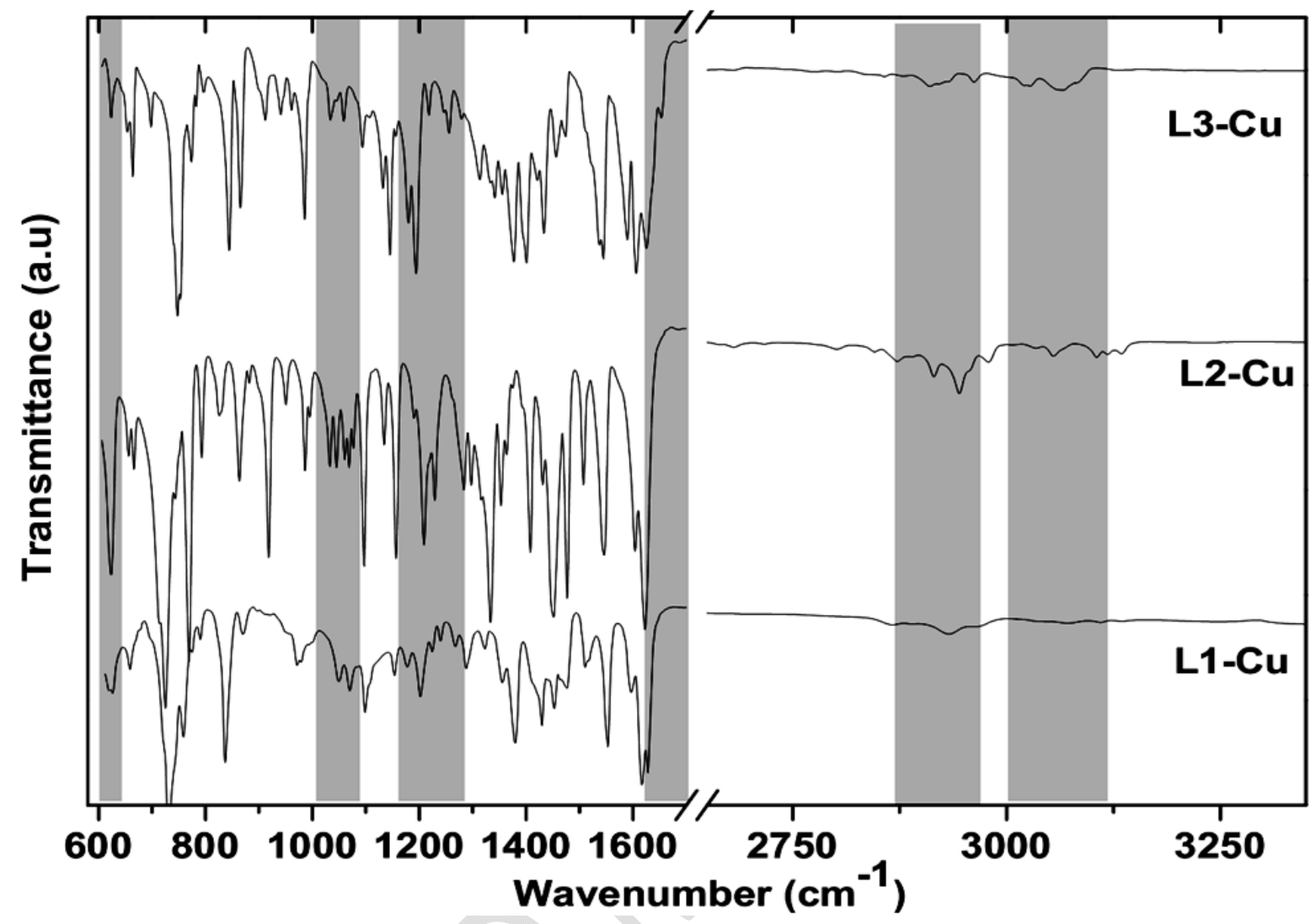

Fig. 3: FTIR spectra of L1-Cu, L2-Cu and L3-Cu.

\begin{tabular}{lccc}
\hline Compounds & $\mathbf{v}(\mathbf{O H})\left(\mathrm{cm}^{-1}\right)$ & $\mathbf{v}(\mathbf{C}=\mathbf{N})\left(\mathrm{cm}^{-1}\right)$ & $\mathbf{v}(\mathbf{M N})\left(\mathrm{cm}^{-1}\right)$ \\
\hline L1 & 3300 & 1630 & - \\
Cu-L1 & - & 1607 & 645 \\
L2 & 3350 & 1626 & - \\
Cu-L2 & - & 1615 & 618 \\
L3 & 3360 & 1625 & - \\
Cu-L3 & - & 1617 & 657 \\
\hline
\end{tabular}

Table 3: FTIR spectral data for ligands and their complexes. 


\subsection{Thermogravimetric analysis}

Thermogravimetric analysis (TGA) of synthesized compounds and their copper (II) complexes provided additional information regarding their thermal stabilities and thermal behavior. Fig. 4a presents TGA results for L1, L2 and L3, showing that the compounds exhibit a good thermal stability with a maximum thermal decomposition at $220^{\circ} \mathrm{C}$ (estimated from derivative curves). This stability can be explained by the presence of intermolecular hydrogen bonds in these salicylaldehyde and 2-hydroxynaphthaldehyde compounds.

From the thermograms of $\mathrm{L}_{1}-\mathrm{Cu}$ and $\mathrm{L}_{2}-\mathrm{Cu}$ complexes, it is possible to detect two steps of the degradation process. The first one starts at $25^{\circ} \mathrm{C}$ to above $300^{\circ} \mathrm{C}$, with the consumption of $50 \%$ of the material at the inflection point, which implies the absence of coordination molecules, like hydration water molecules, in the structure of the complexes. Beyond $300^{\circ} \mathrm{C}$, the organic entity is easily degraded. This stage is followed by another one, with the consumption of $35 \%$ of the remaining material at the inflection point. This percentage is related to the formation of entities, such as copper oxide (metal residues) [45]. Similar observations were made about the $\mathrm{L}_{3}-\mathrm{Cu}$ complex but in the first stage, a weight reduction of $8 \%$ was found between 25 and $200^{\circ} \mathrm{C}$ : this may be attributed to the loss of hydration water molecules (Fig. 4b). 

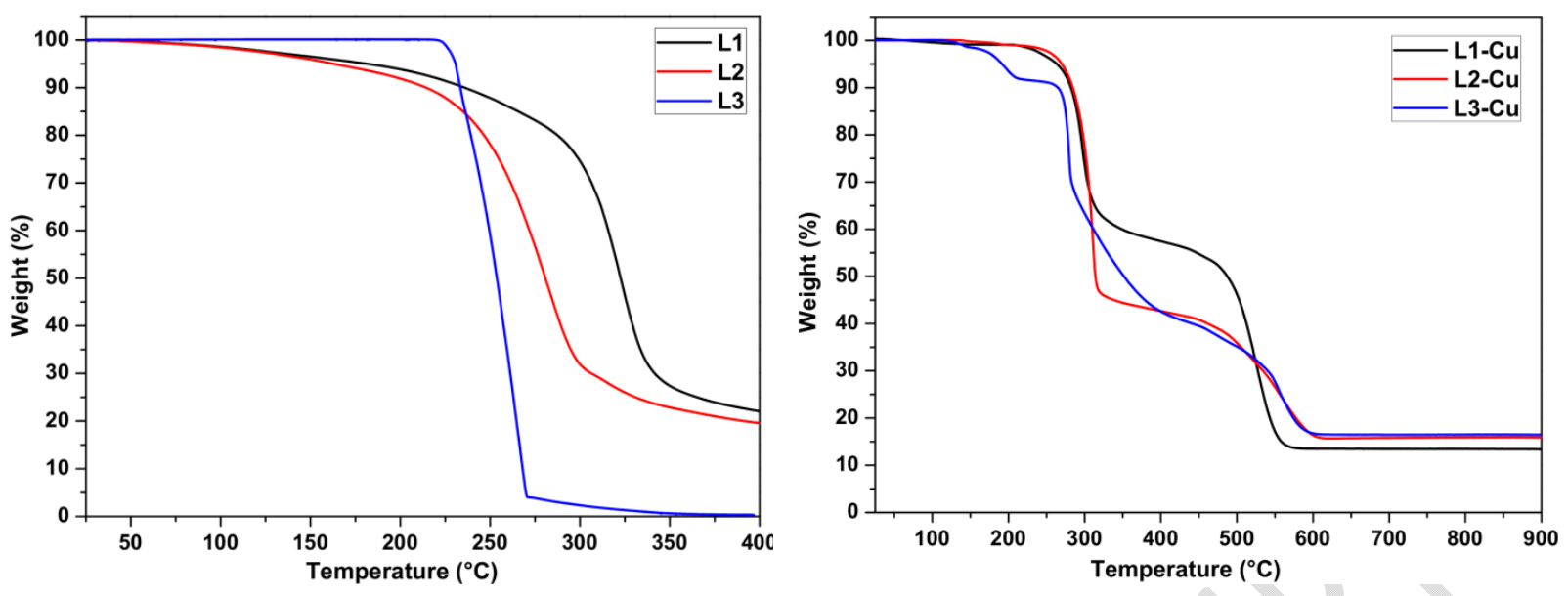

Fig. 4: (a) TGA results from ligands L1, L2 and L3 (b) and their $\mathrm{Cu}(\mathrm{II})$ complexes under nitrogen atmosphere at heating rate of $10^{\circ} \mathrm{C} / \mathrm{min}$.

\subsection{Electrochemical characterization of pyrrole-Cu(II) Schiff base complexes}

The investigation of the electrochemical behavior of the $\mathrm{L} 1-\mathrm{Cu}, \mathrm{L} 2-\mathrm{Cu}$ and $\mathrm{L} 3-\mathrm{Cu}$ complexes by cyclic voltammetry represents an important step in this study, since it allows the determination of different redox couples of these complexes as well as different oxidation potentials which will be used in the polymerization step and ME elaboration.

The electrochemical response of $\mathrm{L} 1-\mathrm{Cu}$ is shown in Fig. $\mathbf{5}$ which was found to be similar to that found for the two other copper complexes. L1-Cu was studied by cyclic voltammetry in acetonitrile solution of $\mathrm{TBAPF}_{6}(0.1 \mathrm{M})$ with a scan rate of $100 \mathrm{mV} / \mathrm{s}$, exploring the potential ranging from $-1.80 \mathrm{~V}$ to $+1.60 \mathrm{~V}$ on platinum and ITO work electrodes for all complexes.

The voltammogram of Fig. 5 of L1-Cu (II) complex on the platinum electrode exhibits five oxidation peaks: $\mathrm{E}_{\mathrm{pa} 1}=-0.743 \mathrm{~V}, \mathrm{E}_{\mathrm{pa} 2}=-0.171 \mathrm{~V}$ and $\mathrm{E}_{\mathrm{pa} 3}=+0.396 \mathrm{~V} / \mathrm{Ag} / \mathrm{AgCl}$, respectively. As already reported for $\mathrm{Cu}(\mathrm{II})$ complexes, the first wave is ascribed for $\mathrm{Cu}(\mathrm{I}) / \mathrm{Cu}(0)$, the second to $\mathrm{Cu}(\mathrm{II}) / \mathrm{Cu}(\mathrm{I})$, and the third one may be attributed to the $\mathrm{Cu}(\mathrm{III}) / \mathrm{Cu}(\mathrm{II})$ for oxidation of the central metal in the complex. The wave at $\mathrm{E}_{\mathrm{pa} 4}=+1.147 \mathrm{~V}$ corresponds to the oxidation of the pyrrole motif, the last wave at $\mathrm{E}_{\mathrm{pa} 5}=+1.437 \mathrm{~V}$ refers to the oxidation of the azomethine 
function of the Schiff base. These results are similar to those reported in the literature $[37,46-$ 47].

For the return sweep presented in Fig. 5, three main reduction waves were observed $\mathrm{E}_{\mathrm{pc} 1}=-0.966 \mathrm{~V}, \mathrm{E}_{\mathrm{pc} 2}=-0.629 \mathrm{~V}$ and $\mathrm{E}_{\mathrm{pc} 3}=-0.172 \mathrm{~V}$, the first can be associated to reduction $\mathrm{Cu}(\mathrm{I})+1 \mathrm{e}^{-} \rightarrow \mathrm{Cu}(0)$ species followed by the second $\mathrm{Cu}(\mathrm{II})+1 \mathrm{e}^{-} \rightarrow \mathrm{Cu}(\mathrm{I})$, and the third peak corresponds to reduction $\mathrm{Cu}(\mathrm{III})+1 \mathrm{e}^{-} \rightarrow \mathrm{Cu}$ (II) of the central metal in the complex. A further reduction broad-shaped peak is observed in the positive potential range between +1.2 and $+1.5 \mathrm{~V} / \mathrm{Ag} / \mathrm{AgCl}$, which corresponds to the reduction of the oxidized azomethine function in the Epa 5 wave.

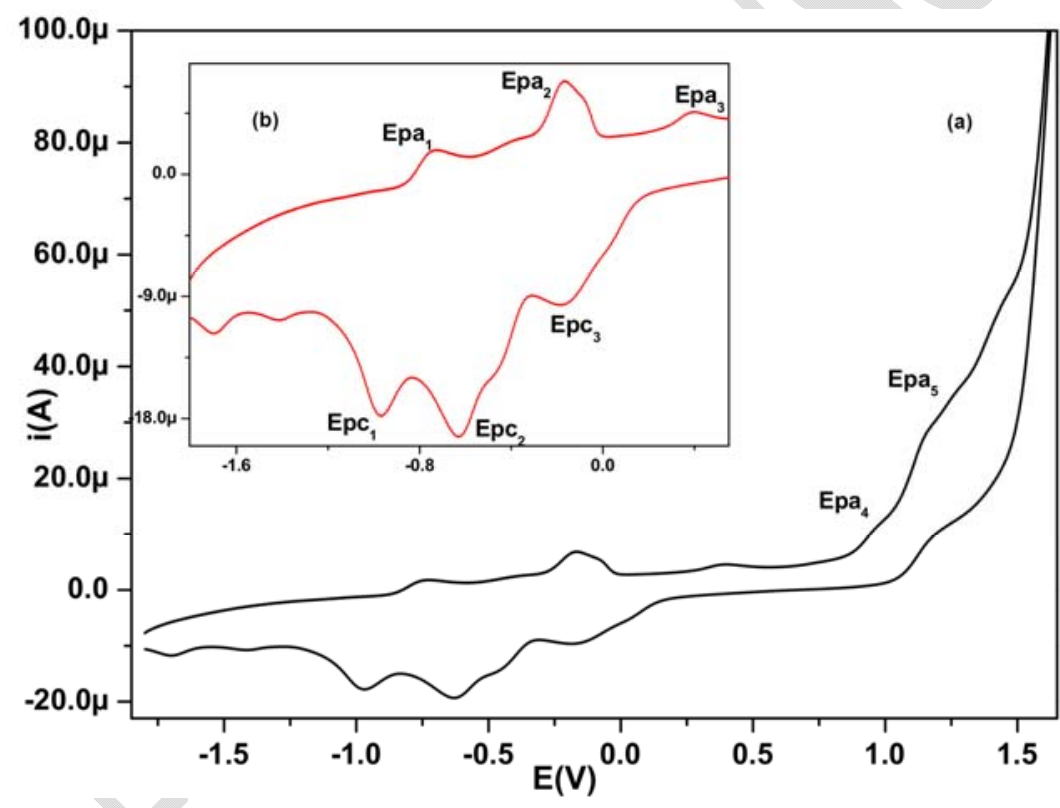

Fig. 5: Voltammetric scan of the L1-Cu ligand $(10 \mathrm{mM})$, recorded on Pt electrode $(\varnothing 3 \mathrm{~mm})$ in acetonitrile solution $\mathrm{TBAPF}_{6}(0.1 \mathrm{M})$ at scan rate $100 \mathrm{mVs}^{-1}$ (a) general and (b) negative potential scan.

The electrochemical behavior of the $\mathrm{L} 2-\mathrm{Cu}$ and $\mathrm{L} 3-\mathrm{Cu}$ complexes, investigated under the same conditions on Pt electrode, are similar to those found in the case of the first complex with some shifts in the potential values (cf. Table 4). 


\begin{tabular}{lllllllll}
\hline Compounds & \multicolumn{3}{c}{ Oxidation $\left(\mathbf{E}_{\mathbf{p a}}\right)$} & & & \multicolumn{2}{c}{ Reduction $\left(\mathbf{E}_{\mathbf{p c}}\right)$} \\
\hline $\mathbf{L 1}-\mathbf{C u}$ & -0.743 & -0.171 & +0.396 & +1.147 & +1.437 & -0.966 & -0.629 & -0.172 \\
$\mathbf{L 2}-\mathbf{C u}$ & -0.932 & -0.061 & +0.520 & +1.191 & +1.405 & -1.232 & -0.906 & - \\
$\mathbf{L 3 - C u}$ & -0.523 & -0.153 & +0.462 & +0.892 & +1.454 & -0.930 & - & -0.174 \\
\hline
\end{tabular}

Table 4: Cyclic voltammetry data (Pt work electrode). Compounds: $1 \mathrm{mM}$ in acetonitrile, $\mathrm{TBAPF}_{6}(0.1 \mathrm{M})$, E-values (V vs $\mathrm{Ag} / \mathrm{AgCl}$ sat) $\mathrm{E}_{\mathrm{pa}}$ and $\mathrm{E}_{\mathrm{pc}}$ represent anodic and cathodic peak potentials, respectively.

The electrochemical responses of the copper complexes were also studied using an ITO electrode, under the same conditions, in acetonitrile, at a scan rate of $100 \mathrm{mVs}^{-1}$. In general, almost the same redox processes were observed: $\mathrm{Cu}(\mathrm{I}) / \mathrm{Cu}(0), \mathrm{Cu}(\mathrm{II}) / \mathrm{Cu}(\mathrm{I})$ and $\mathrm{Cu}(\mathrm{III}) / \mathrm{Cu}(\mathrm{II})$, with pyrrole and azomethine oxidative peaks, and two reduction peaks were observed as shown in Table 5. The main difference with the results obtained on Pt concerns the current intensities (peak heights) which are important when an ITO electrode was used, mainly due to the nature of the material (conductivity), and the surface area $\left(\mathrm{A}=1 \mathrm{~cm}^{2}\right)$; the second difference is related to the displacement of the potential values which were shifted considerably.

\begin{tabular}{llllllllll}
\hline Compounds & \multicolumn{4}{c}{ Oxidation $\left(\mathbf{E}_{\mathbf{p a}}\right)$} & & \multicolumn{3}{c}{ Reduction $\left(\mathbf{E}_{\mathbf{p c}}\right)$} \\
\hline $\mathbf{L 1}-\mathbf{C u}$ & -1.061 & -0.341 & +0.214 & +0.802 & +1.357 & -1.371 & -0.951 & -0.376 \\
$\mathbf{L 2 - C u}$ & -1.071 & -0.734 & +0.529 & +1.046 & +1.531 & -1.674 & -0.936 & - \\
$\mathbf{L 3 - C u}$ & -0.682 & -0.122 & +0.439 & +1.213 & +1.431 & -1.007 & - & -0.493 \\
\hline
\end{tabular}

Table 5: Cyclic voltammetry data on ITO work electrode. Compounds: $1 \mathrm{mM}$ in acetonitrile, $\operatorname{TBAPF}_{6}(0.1 \mathrm{M})$, E-values (V vs $\mathrm{Ag} / \mathrm{AgCl}$ sat). $\mathrm{E}_{\mathrm{pa}}$ and $\mathrm{E}_{\mathrm{pc}}$ stand for anodic and cathodic peaks potentials, respectively. 


\subsection{Electropolymerisation of complexes and achievement of ME}

The electrochemical polymerization of the three copper complexes was achieved by cyclic voltammetry, applying a scan rate of $100 \mathrm{mV} / \mathrm{s}$, using an acetonitrile solution with $\mathrm{TBAPF}_{6}$ $(0.1 \mathrm{M})$ as electrolyte support, on Pt and ITO electrodes. After the electropolymerization procedure, three new MEs were obtained for each support, i.e. ME-poly $\left(\mathrm{L}_{\mathrm{i}}-\mathrm{Cu}\right)-\mathrm{Pt}$ and $\mathrm{ME}-$ poly $\left(\mathrm{L}_{\mathrm{i}}-\mathrm{Cu}\right)-\mathrm{ITO}$, with $\mathrm{i}=1,2$ and 3 .

The first polymerization experiment was carried out with the L1-Cu complex on Pt electrode taking into account the previously determined oxidation potential of the pyrrole motif, $\mathrm{E}_{\mathrm{pa} 4}=$ $+1.147 \mathrm{~V}$. A decrease of the peak current $\mathrm{i}$ occurred during repeated potential scans between $0.25 \mathrm{~V}$ and $+1.25 \mathrm{~V}$ and did not yield any film (Fig. 6). This result was probably related to an over-oxidation of the polypyrrole matrix [37].

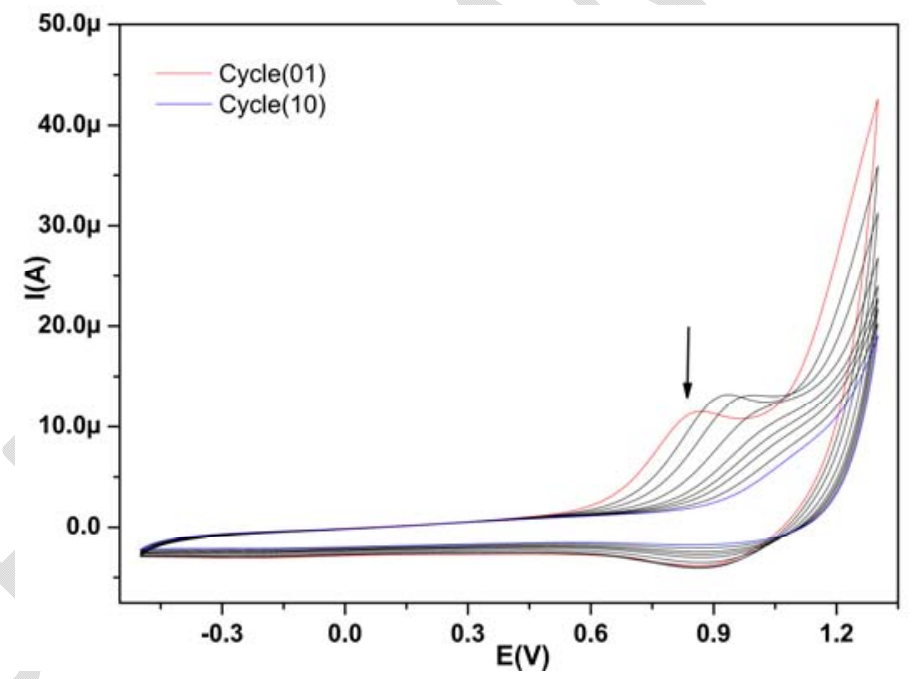

Fig. 6: Cyclic voltammograms showing electrodeposition test of poly-[L1-Cu] onto a platinum electrode in acetonitrile solution $\operatorname{TBAPF}_{6}(0.1 \mathrm{M})$ at scan rate $100 \mathrm{mV} / \mathrm{s}$ applying 10 scans between +1.25 and $-0.25 \mathrm{~V}$.

For this reason, and applying the same work conditions, the electropolymerization of $1 \mathrm{mM}$ (L1-Cu) was achieved by application of repetitive voltage cycles in a reduced potential range 
between $-1.80 \mathrm{~V}$ and $+0.65 \mathrm{~V}$. The voltammograms on Fig. 7a display a continuous growth of the values of the anodic $\left(\mathrm{i}_{\mathrm{pa}}\right)$ and cathodic $\left(\mathrm{i}_{\mathrm{pc}}\right)$ current magnitudes, with a current jump of $\Delta \mathrm{i}$ $\approx 15 \mu \mathrm{A}$ between the first and the last cycle, hence confirming the build-up of the attractive Poly ( $\mathrm{L} 1-\mathrm{Cu})$ film on the Pt-electrode surface. Moreover, the polymer formation was corroborated by the appearance of a new reduction wave of polypyrrole at $+0.25 \mathrm{~V}$. Likewise, the two other monomers $(\mathrm{L} 2-\mathrm{Cu})$ and $(\mathrm{L} 3-\mathrm{Cu})$ were electrodeposited on $\mathrm{Pt}$ and the corresponding ME-Poly (L2-Cu)-Pt and ME-Poly (L3- Cu)-Pt were obtained, as illustrated in Fig. $7 \mathbf{b}$ and $\mathbf{c}$.
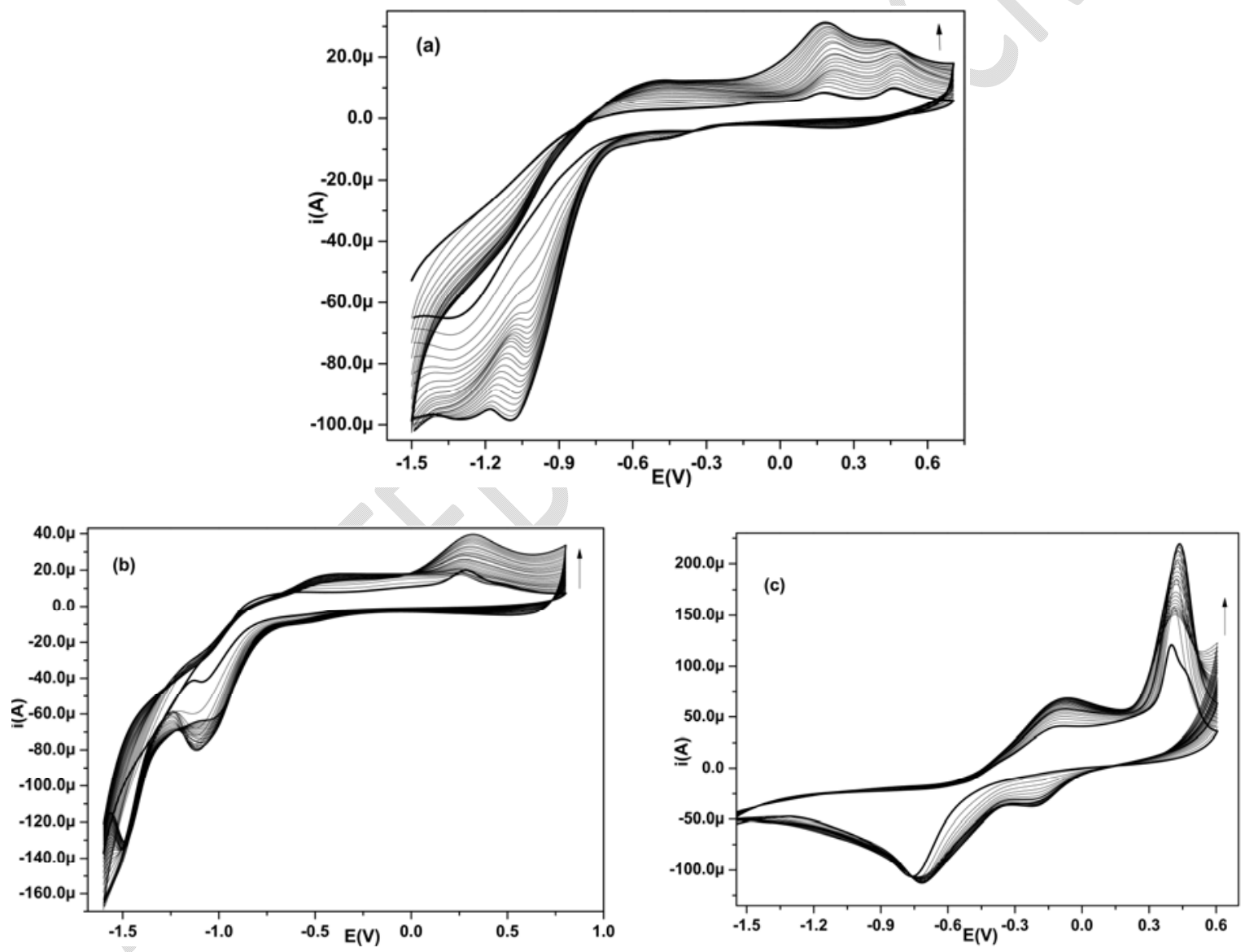

Fig. 7: Cyclic voltammograms of evolution of the electrodeposition applying 25 scans, at scan rate $100 \mathrm{mV} / \mathrm{s}$ in acetonitrile- $\mathrm{TBAPF}_{6}(0.1 \mathrm{M})$ on Pt electrodes $(3 \mathrm{~mm} \varnothing)$ : (a) Poly (L1-Cu), (b) Poly (L2-Cu), (c) Poly (L3-Cu) films. 
Once the Poly $\left(\mathrm{L}_{\mathrm{i}}-\mathrm{Cu}\right)(\mathrm{i}=1,2$ and 3) films were electrodeposited on the Pt-electrode, the obtained ME-poly $\left(\mathrm{L}_{\mathrm{i}}-\mathrm{Cu}\right)-\mathrm{Pt}$ were rinsed with ultra pure water and acetonitrile; and then stored in the same solution (a fresh electrolytic solution without monomer). The recorded cyclic voltammograms were gathered in Fig. 8. For all ME, one observes the same redox system of polypyrrole matrix.
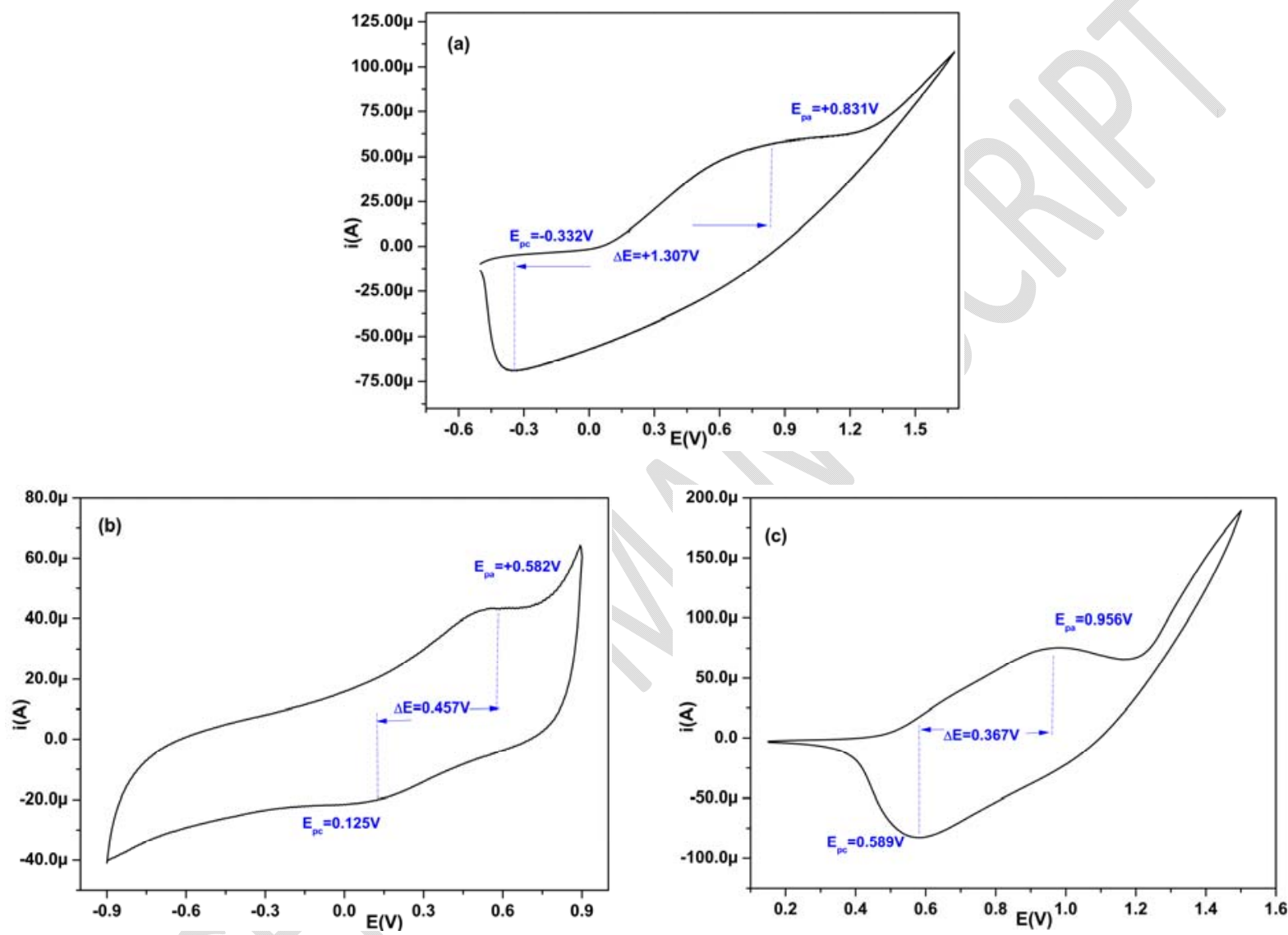

Fig. 8: Voltametric scans after electrode transfer in acetonitrile $\mathrm{TBAPF}_{6}(0.1 \mathrm{M})$ for $\mathrm{ME}$ onto platinum at scan rate $50 \mathrm{mV} / \mathrm{s}$ : (a) ME (L1-Cu)Pt, (b) ME (L2-Cu)Pt, (c) ME (L3-Cu)Pt.

Similarly, poly $\left(\mathrm{L}_{1}-\mathrm{Cu}\right)$, poly $\left(\mathrm{L}_{2}-\mathrm{Cu}\right)$ and poly $\left(\mathrm{L}_{3}-\mathrm{Cu}\right)$ were electrodeposited, under the above mentioned conditions, on optically transparent ITO electrodes $\left(A=1 \mathrm{~cm}^{2}\right)$, with a $1 \mathrm{mM}$ monomer concentration. Three new ME were elaborated; these are ME-poly $\left(\mathrm{L}_{\mathrm{i}}-\mathrm{Cu}\right)-\mathrm{ITO}$, with $i=1,2$ and 3 . The same observations are made in the case of Pt electrodes. The growth 
of polymer films was evidenced by continuously increasing values of the current peaks. The polymers electrodeposited on the MEs were found to be very stable and showed good adherence (Fig. 9).
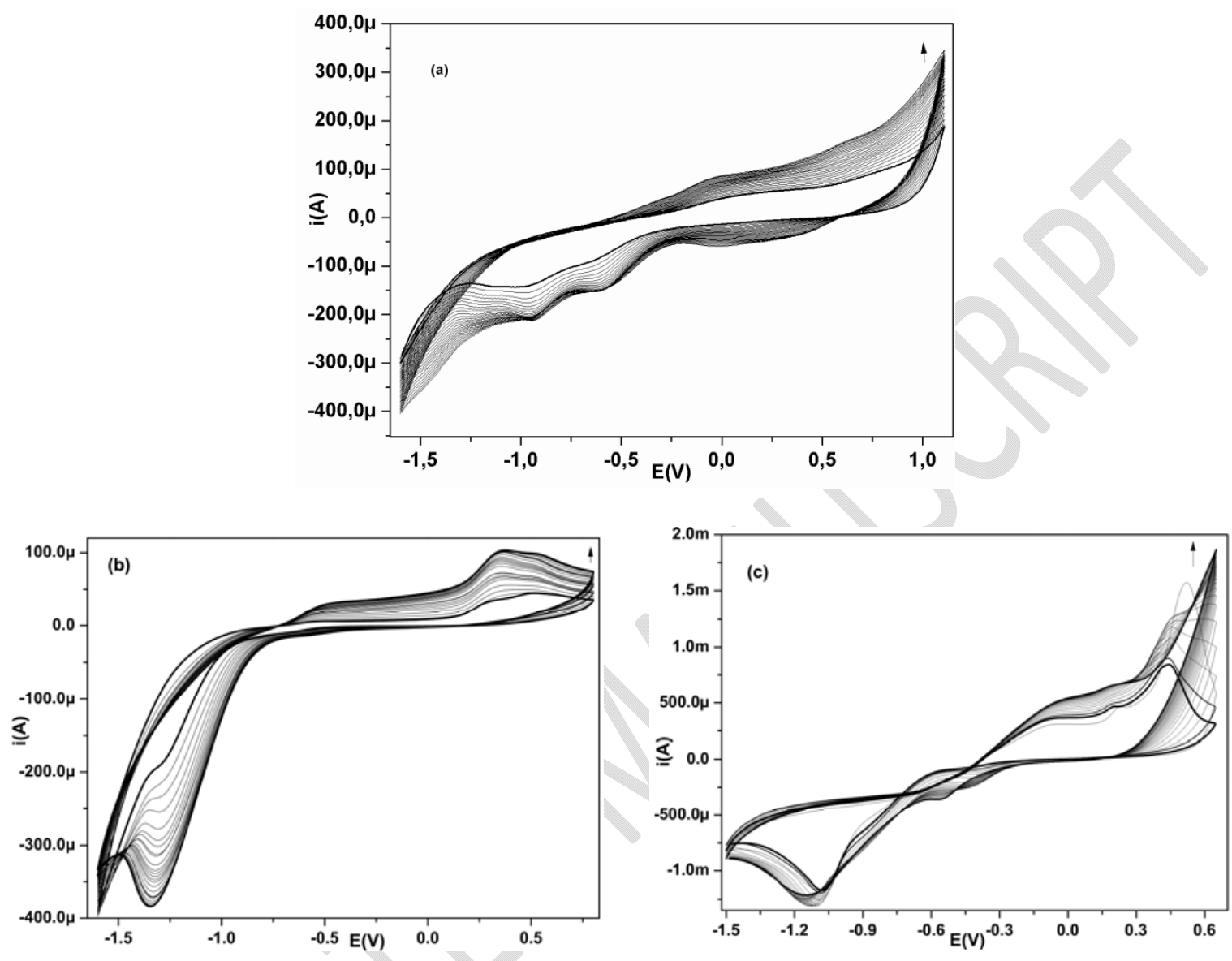

Fig. 9: Cyclic voltammograms of evolution of the electrodeposition with 25 scans, at scan rate $100 \mathrm{mV} / \mathrm{s}$ in acetonitrile- $\mathrm{TBAPF}_{6}(0.1 \mathrm{M})$ on ITO electrodes $\left(\mathrm{A}=1 \mathrm{~cm}^{2}\right)$ : (a) Poly $(\mathrm{L} 1-\mathrm{Cu})$, (b) Poly (L2-Cu), (c) Poly (L3-Cu).

Like ME obtained on platinum, the obtained ME-poly $\left(\mathrm{L}_{\mathrm{i}}-\mathrm{Cu}\right)-\mathrm{ITO}$ were rinsed with ultra pure water and acetonitrile; and then stored in the same solution (a fresh electrolytic solution without monomer). Cyclic voltammograms ME-poly $\left(\mathrm{L}_{\mathrm{i}}-\mathrm{Cu}\right)-\mathrm{ITO}$ are presented in Fig. 10. 

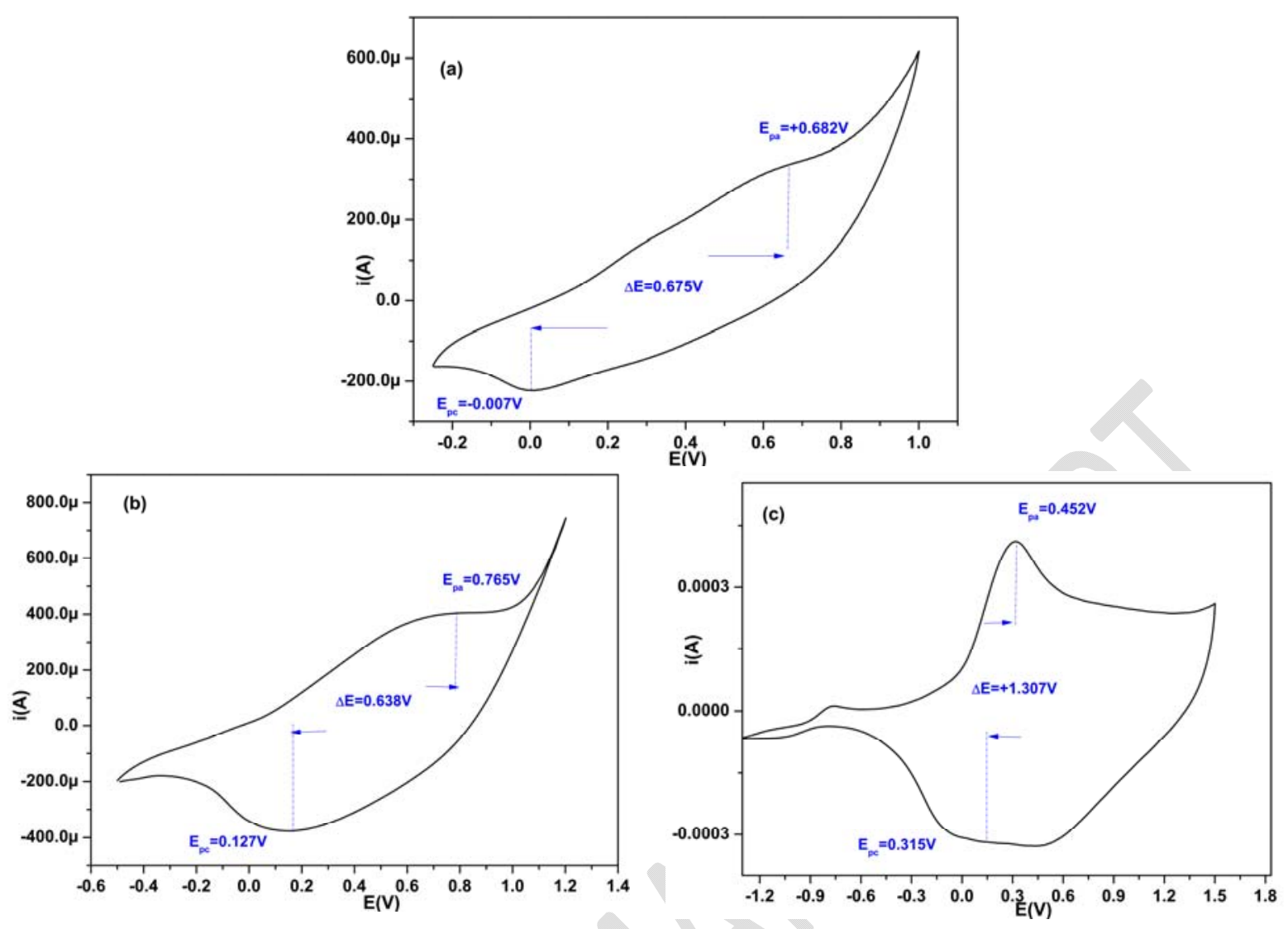

Fig. 10: Voltametric scans after electrode transfer in acetonitrile $\mathrm{TBAPF}_{6}(0.1 \mathrm{M})$ for $\mathrm{ME}$ onto ITO at scan rate $50 \mathrm{mV} / \mathrm{s}$ : (a) ME (L1-Cu)ITO, (b) ME (L2-Cu)ITO, (c) ME (L3-Cu)ITO.

\subsection{Characterization of Poly $\left(\mathrm{L}_{\mathrm{i}}-\mathrm{Cu}\right)-\mathrm{ITO}$ films}

The characterization of the obtained poly(complexes) films onto ITO-substrates was undertaken by FTIR spectroscopy, and their morphology was observed by SEM coupled to EDX, allowing to obtain the elemental analysis.

\subsubsection{FTIR spectroscopy}

Fig. 11 shows FTIR spectra of poly $(\mathrm{L} 1-\mathrm{Cu})$, poly $(\mathrm{L} 1-\mathrm{Cu})$ and poly $(\mathrm{L} 1-\mathrm{Cu})$ complexes films deposited on ITO electrode. These spectra present bands which can be attributed to functional groups of the repeating unit of each polymeric film. The most intense band corresponds to the 
$\delta(\mathrm{C}-\mathrm{H})$ deformation (out of plane) of the poly(pyrrole) backbone at 830,850 and $880 \mathrm{~cm}^{-1}$ successively for Poly (L1-Cu), Poly (L2-Cu) and Poly (L3-Cu), respectively, and the bands between 1050 and $1125 \mathrm{~cm}^{-1}$ were assigned to the $\mathrm{N}-\mathrm{C}$ and $=\mathrm{C}-\mathrm{H}$ plane vibrations. All these bands indicate the formation of polypyrrole backbone. The absorption bands observed between 1400 and $1550 \mathrm{~cm}^{-1}$ were associated to the $\nu(C=C)$ bond stretching of the phenyl ring. The azomethine function $\vee(\mathrm{C}=\mathrm{N})$ was present in all structures; their bands were found successively at 1620, 1625 and $1615 \mathrm{~cm}^{-1}$ for Poly (L1-Cu), Poly (L2-Cu) and Poly (L3-Cu), respectively.

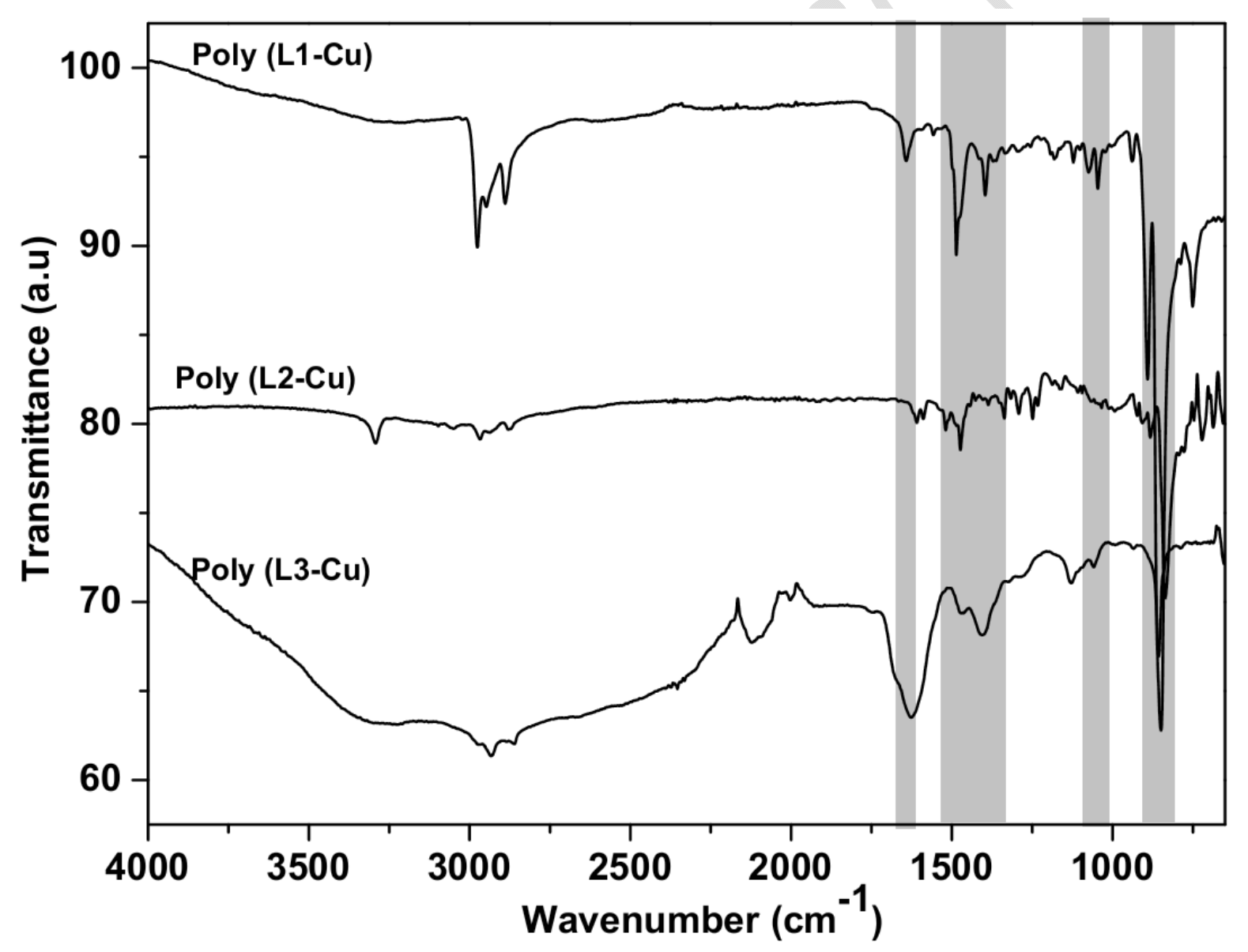

Fig. 11: FTIR spectra of poly (L1-Cu), poly (L2-Cu) and poly (L1-Cu), on ITO-electrodes. 


\subsubsection{SEM analysis}

In order to explore the surface morphology of the different films deposited on ITO, SEM analysis was carried out; the samples were chromium plated prior to analysis. Images with different magnifications are presented on Fig. 12, for each analyzed film.
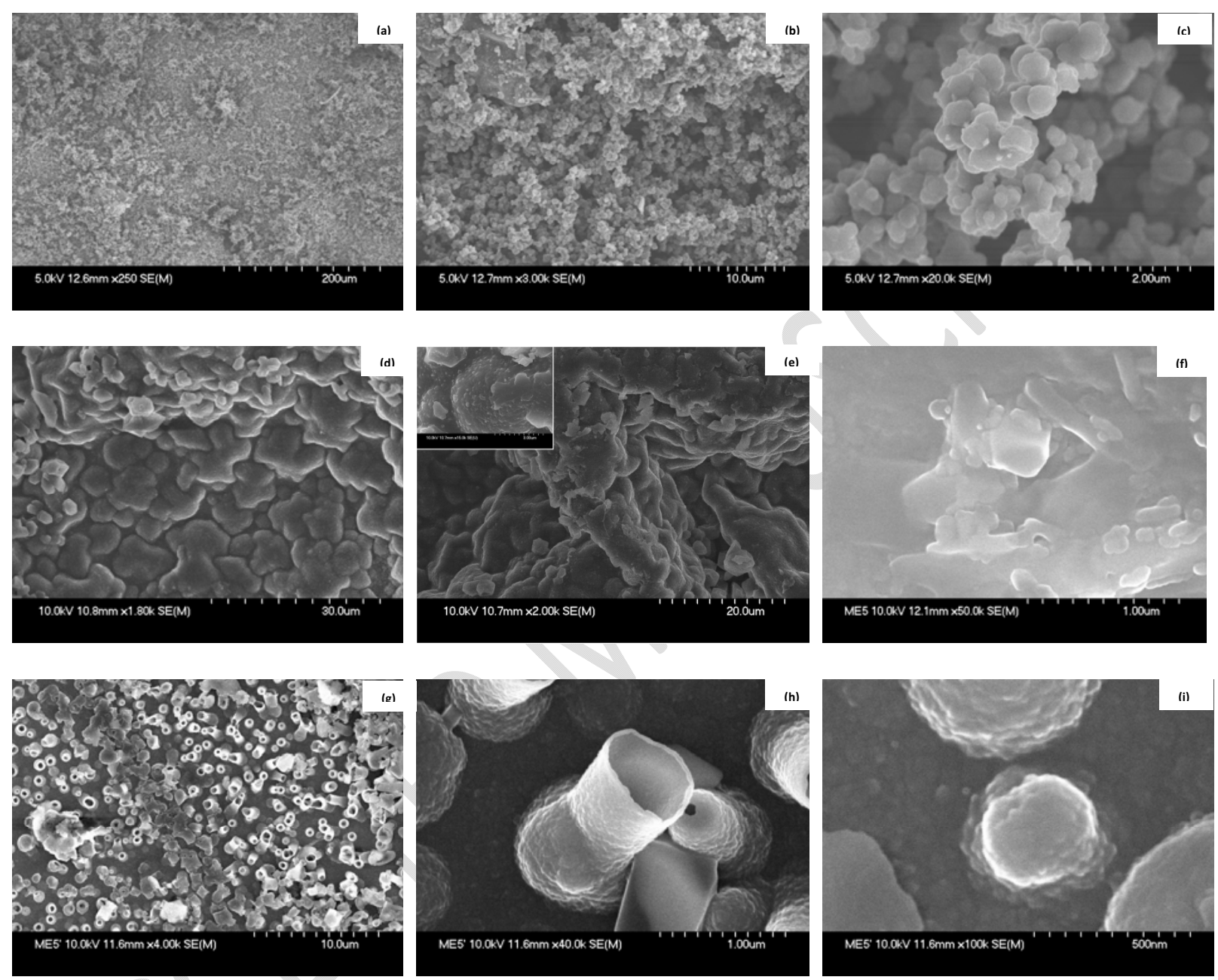

Fig. 12: SEM images of ME-poly(L1-Cu) exhibiting various magnifications. The following numbers represent the length of the scaling bars (a) $200 \mu \mathrm{m}$, (b) $10 \mu \mathrm{m}$, (c) $2 \mu \mathrm{m}$ after 25 scans; ME-poly(L2-Cu): (d) $30 \mu \mathrm{m}$, (e) $20 \mu \mathrm{m}$ and $3 \mu \mathrm{m}$ after 25 scans, and (f) $2 \mu \mathrm{m}$ after 10 cycles;

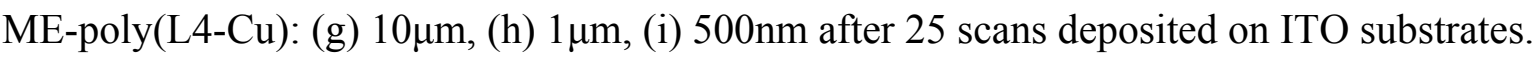


In general, irregular and heterogeneous surfaces were observed for the three samples. On the surface of poly ( $\mathrm{L} 1-\mathrm{Cu})$ and poly (L2-Cu) films, a covering was observed over the entire (compact) surface with the formation of well-known globular structures in the case of polypyrrole. These spheres represent a diameter of approximately $2 \mu \mathrm{m}$. On the other hand, surface covering and then a tubular evolution was observed in the case of poly (L3-Cu), with the formation of connections or bridges between these tubes.

\subsubsection{EDX characterization}

In addition to the investigations of the sample morphologies, the elemental compositions of the formed polymers were determined by EDX analysis. Fig. 13 displays EDX spectra of the three complexes films electrodeposited on ITO electrode, exhibiting peaks of carbon, nitrogen and oxygen which represent the essential elements that constitute the poly(pyrrole) matrix, while the presence of Copper $(\mathrm{Cu})$ peak at $8.040 \mathrm{keV}$ (most important $\mathrm{K} \alpha$ ) reveals that $\mathrm{Cu}$ (II) complexes were successfully electropolymerized and incorporated within the polypyrrole matrix. Small peaks of phosphate and fluorine indicate the presence of traces of electrolyte support $\left(\mathrm{TBAPF}_{6}\right)$ and chromium $(\mathrm{Cr})$ provided from the metallization procedure of samples during their preparation to this analysis.

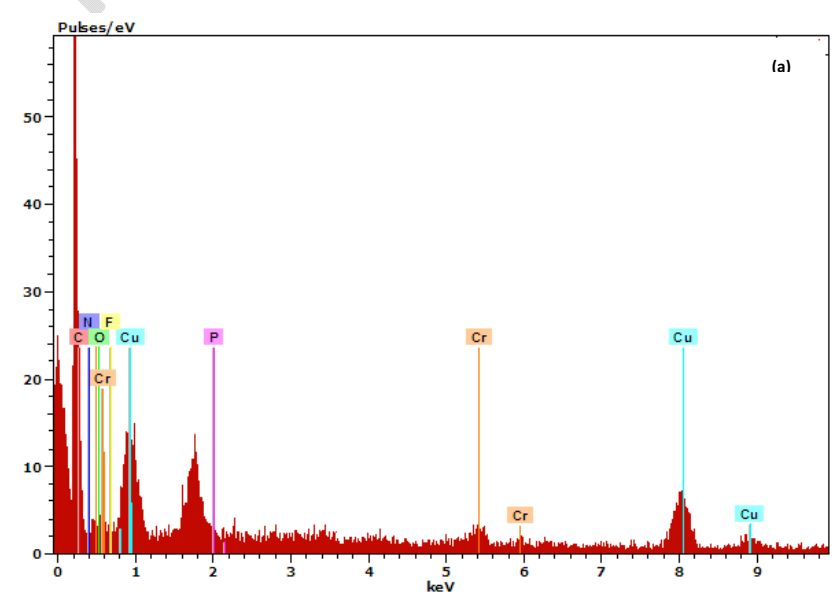



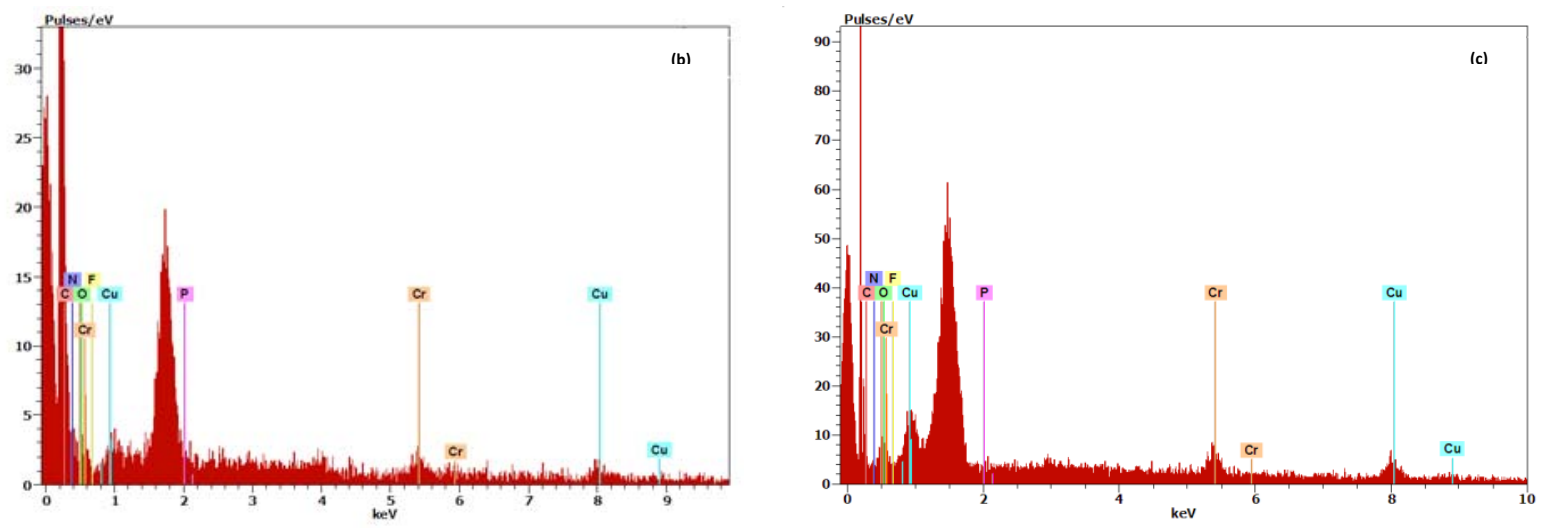

Fig. 13: EDX spectra of (a) ME-poly(L1-Cu), (b) ME-poly(L2-Cu), (c) ME-poly(L3-Cu) after 25 scans deposited on ITO electrodes.

\subsection{Catalytic properties of elaborated MEs}

\subsubsection{Electrochemical reduction of acetophenone}

Acetophenone is a good quality substrate used to demonstrate the electrocatalytic activity of a material. Several reports referred to the application of this substrate for catalytic reactions, either on metal electrodes such as $\mathrm{Pd}, \mathrm{Pt}, \mathrm{Ni}$, and $\mathrm{Cu}$ [48-50], or on MEs [51-53].

In the present work, acetophenone reduction experiments were undertaken on ME-poly(L1$\mathrm{Cu})$-Pt in an aqueous solution of $\mathrm{TBAClO}_{4}(0.1 \mathrm{M})$. The results shown in Fig. 14a confirm clearly the catalytic capacity of ME-poly $(\mathrm{L} 1-\mathrm{Cu})-\mathrm{Pt}$, since a remarkable increase in current intensity of the reduction peak was observed as function of the quantity of added acetophenone compared to the blank sample $(0 \mu \mathrm{L})$, accompanied by a slight shift of reduction potential.

Fig. 14b represents an increase of the value of the cathodic current ipc as function of the amount of injected acetophenone; the value of ipc goes up from 7 to $42 \mu \mathrm{A}$ for substrate volume values varying from 0 to $40 \mu \mathrm{L}$, respectively. This may be explained first by the diffusion of the substrate into the bulk of the ME, and then by the reduction procedure which occurs through the interaction of the acetophenone molecules with the catalytic sites of the 
ME. Here, the complex modified electrode acts as a mediator that transfers the electrons to acetophenone, the latter reduces to give a radical ion and then the final product. These processes are confirmed since every time the concentration of the substrate in the solution will be increased, the demand for electrons will increase as well, which leads to the observed increase of cathodic current intensities Ipc $[\mathbf{5 4}, \mathbf{5 5}]$.
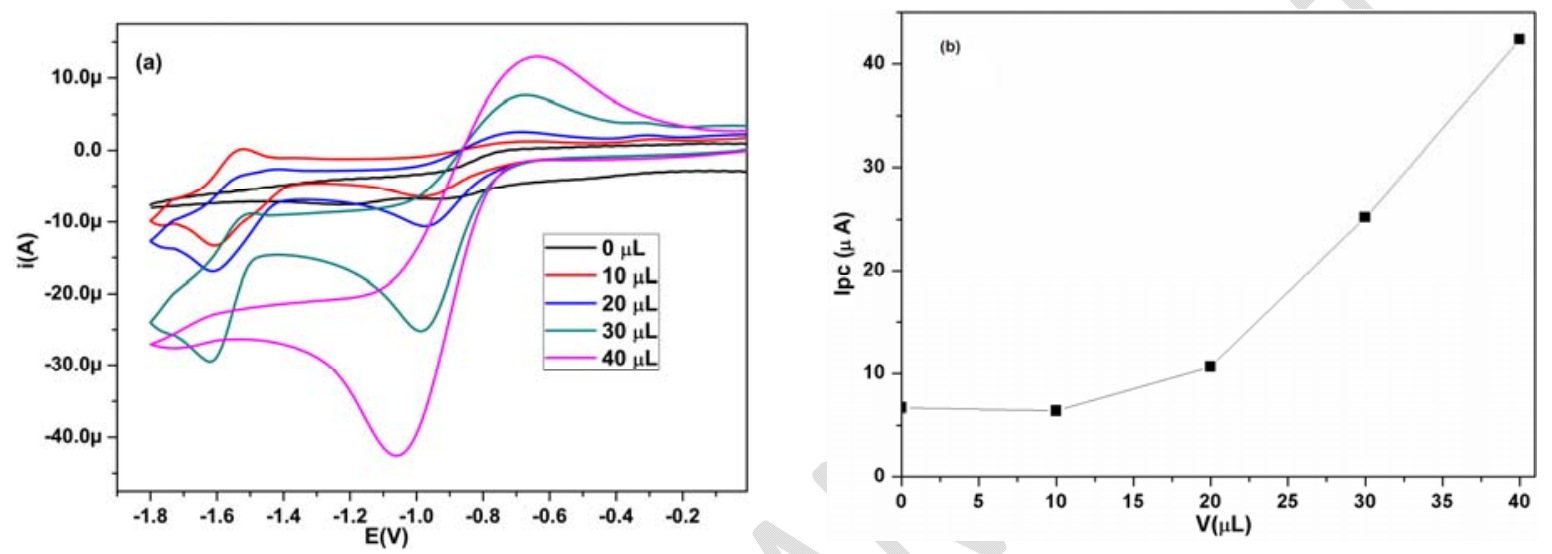

Fig. 14: (a) Cyclic voltammograms recorded for various volumes $(10-40 \mu \mathrm{L})$ of acetophenone on ME-poly(L1-Cu)-Pt in aqueous medium $\mathrm{TBAClO}_{4}(0.1 \mathrm{M})$, at a scan rate of $50 \mathrm{mV} / \mathrm{s}$. (b) Plot of cathodic current $\mathrm{I}_{\mathrm{pc}}$, recorded for different quantities of injected acetophenone.

\subsubsection{Reduction of carbon dioxide}

The interest in the electrochemical reduction of $\mathrm{CO}_{2}$ has continued to grow and represents still an important issue. The production of this molecule has harmful effects and serious impact on the environment, hence many efforts are undertaken to limit and reduce $\mathrm{CO}_{2}$ concentration worldwide, implying the development of methods and materials adapted to this purpose. Generally, electroreduction of $\mathrm{CO}_{2}$ is difficult to achieve due to its great thermodynamic stability, hence there is need to use mediators. Following these lines, different materials have been developed to attain much lower $\mathrm{CO}_{2}$ levels [56-59]. 
In this context, electroreduction of $\mathrm{CO}_{2}$ was undertaken using $\mathrm{ME}-$ poly $(\mathrm{L} 1-\mathrm{Cu})-\mathrm{Pt}$ in an aqueous solution of $0.1 \mathrm{M} \mathrm{TBAClO} 4$, at a rate of $50 \mathrm{mV} / \mathrm{s}$. Experiments were first conducted in a $\mathrm{N}_{2}$ saturated medium, and then repeated in a medium saturated with $\mathrm{CO}_{2}$. The saturation of the latter solution leads to a $\mathrm{pH}$-value equal to 3.5 , and drastic changes of the shape of the recorded voltammograms can be observed (Fig. 15).

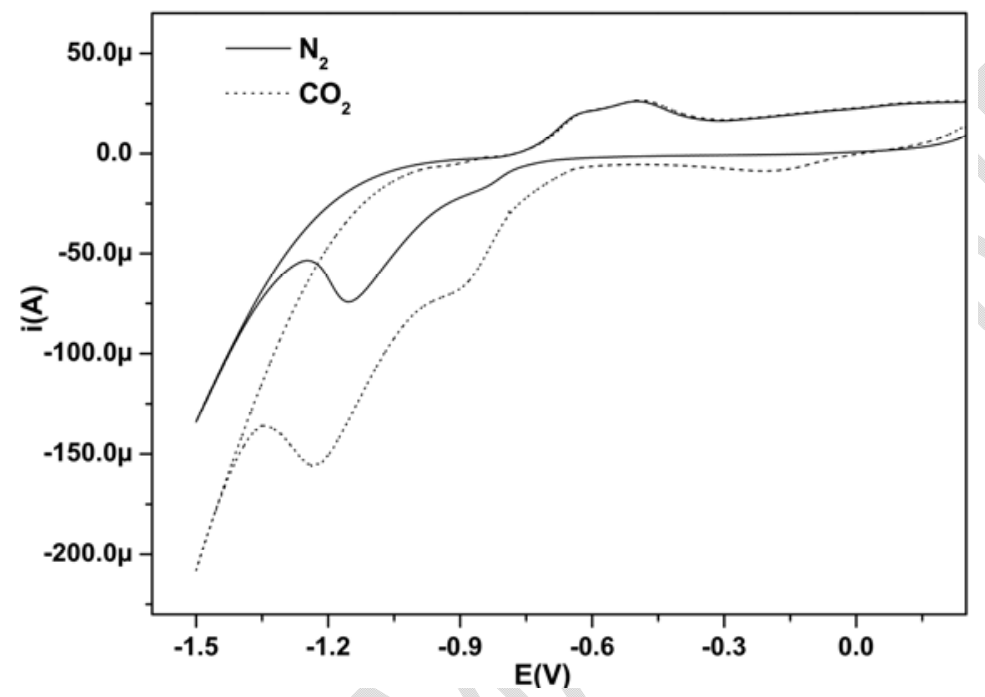

Fig. 15: Voltammograms corresponding to the electrocatalytic reduction of $\mathrm{CO}_{2}$ on $\mathrm{ME}-$ poly(L1-Cu)-Pt complexes films at $50 \mathrm{mV} / \mathrm{s}$ in aqueous medium, $\mathrm{TBAClO}_{4}(0.1 \mathrm{M})$.

One can also notice the presence of a first reduction wave at $-0.88 \mathrm{~V}$, which corresponds to the induction and fixation of $\mathrm{CO}_{2}$ on the support, during the reduction $\mathrm{Cu}(\mathrm{II}) \rightarrow \mathrm{Cu}$ (I). As a consequence poly $\left[\mathrm{L} 1-\mathrm{Cu}(\mathrm{II})-\mathrm{CO}_{2}\right]$ was formed representing an electron transfer on the $\mathrm{ME}$ that could be explained by the formation of $\mu$-oxo fixation of $\mathrm{CO}_{2}$ on the complex polymer as discussed in literature $[\mathbf{3 8}, \mathbf{5 9}]$. A second reduction wave was observed at $-1.23 \mathrm{~V}$. In this case, the reduction currents were much larger (discharge) and this might be explained by the direct reduction of $\mathrm{CO}_{2}$ on copper in the complex with a ratio of the electrocatalytic currents $\mathrm{I}_{\mathrm{pc}}$ $\left(\mathrm{CO}_{2}\right) / \mathrm{I}_{\mathrm{pc}}\left(\mathrm{N}_{2}\right)$ approximately equal to 2.1 . This result demonstrates the efficiency of electroreduction of $\mathrm{CO}_{2}$ on $\mathrm{ME}-$ poly( $\left.\mathrm{L} 1-\mathrm{Cu}\right)-\mathrm{Pt}$ support. 


\section{Conclusion}

In summary, this work allowed to successfully synthesize new Schiff base ligands, bearing pyrrole moieties in their structures, as well as their $\mathrm{Cu}(\mathrm{II})$ complexes by means of a simple method; they were then characterized using spectroscopic and thermal analysis techniques.

In addition, new and original MEs, made of poly $\left(\mathrm{L}_{1}-\mathrm{Cu}\right)$, poly $\left(\mathrm{L}_{2}-\mathrm{Cu}\right)$ and poly $\left(\mathrm{L}_{3}-\mathrm{Cu}\right)$ films, were elaborated by electropolymerization of these complexes on Pt and ITO electrodes using cyclic voltammetry. The obtained polymer films were characterized by FTIR, SEM, and EDX techniques. Finally, these MEs showed highly efficient catalytic activity for the electrochemical reduction of acetophenone and $\mathrm{CO}_{2}$.

\section{Acknowledgements}

This work has been accomplished in the framework of an international research program. The authors gratefully acknowledge the support of the Algerian Ministry of Higher Education and Scientific Research, the University USTOMB of Oran/Algeria, University of Sidi Bel Abbes (UDL), the CNRS, and the University of Lille - Sciences and Technologies/France. 


\section{References}

[1] Khan S, Chattopadhyay S, Al Masum A, Maidul Islam M, Drew MGB, Bauzá A, Frontera

A. Observation of $\pi$-hole interactions in the solid state structures of three new copper (II) complexes with a tetradentate $\mathrm{N}_{4}$ donor Schiff base: Exploration of their cytotoxicity against MDA-MB 468 cells. Polyhedron 2017;123:334-343.

[2] Li X, Bi CF, Fan YH, Zhang X, Meng XM, Cui LM. Synthesis, crystal structure and anticancer activity of a novel ternary copper(II) complex with Schiff base derived from 2amino-4-fluorobenzoic acid and salicylaldéhyde. Inorg Chem Commun 2014; 50: 35-41.

[3] Raman N, Selvan A, Sudharsan S. Metallation of ethylenediamine based Schiff base with biologically active $\mathrm{Cu}(\mathrm{II}), \mathrm{Ni}(\mathrm{II})$ and $\mathrm{Zn}(\mathrm{II})$ ions: Synthesis, spectroscopic characterization, electrochemical behaviour, DNA binding, photonuclease activity and in vitro antimicrobial efficacy, Spectrochim Acta: A 2011;79:873-883.

[4] Swami BL, Ikram S. Synthesis of a new Schiff-base complex based on $\mathrm{Cu}$ and its inference in PVC-based membrane as an electroactive material. Asia-Pac. J Chem Eng $2015 ; 10: 369-376$.

[5] Fu Y, Li P, Bu L, Wang T, Xie Q, Chen J, Yao S. Exploiting Metal-Organic Coordination Polymers as Highly Efficient Immobilization Matrixes of Enzymes for Sensitive Electrochemical Biosensing. Anal Chem 2011;83:6511-6517. 
[6] Sánchez CO, Bèrnede JC, Cattin L, Makha M, Gatica N. Schiff base polymer based on triphenylamine moieties in the main chain. Characterization and studies in solar cells. Thin Solid Films 2014;562:495-500.

[7] Nassar AM, Hassan AM, Shoeib MA, El kmash AN. Synthesis, Characterization and Anticorrosion Studies of New Homobimetallic Co(II), Ni(II), Cu(II), and Zn(II) Schiff Base Complexes. J Bio Tribo Corros 2015;1-19.

[8] Naeimi A, Saeednia S, Yoosefian M, Rudbari HA, Nardoe VM. A novel dinuclear Schiff base copper complex as an efficient and cost effective catalyst for oxidation of alcohol: Synthesis, crystal structure and theoretical studies. J Chem Sci 2015;127:1321-1328.

[9] Zhang Z, Li X, Wang C, Zhang C, Liu P, Fang T, Xiong Y, Xu W. A novel dinuclear Schiff-base copper(II) complex modified electrode for ascorbic acid catalytic oxidation and determination. Dalton Trans 2012;41:1252-1258.

[10] Routaray A, Mantri S, Nath N, Sutar A K, Maharana T. Polymerization of lactide and synthesis of block copolymer catalyzed by copper (II) Schiff base complex. Chinese Chem Lett 2016;12:1763-1766.

[11] Leonardi SG, Bonyani M, Ghosh K. Dhara AK, Lombardo L, Donato N, Neri G. Development of a Novel Cu(II) Complex Modified Electrode and a Portable Electrochemical Analyzer for the Determination of Dissolved Oxygen (DO) in Water. Chemosensors $2016 ; 4: 1-10$ 
[12] Cui BB, Mao Z, Chen Y, Zhong YW, Yu G, Zhan C, Yao J. Tuning of Resistive Memory Switching in Electropolymerized Metallopolymeric films. Chem Sci 2015;6:13081315.

[13] Vereshchagin AA, Sizov VV, Verjuzhskij S, Hrom SI, Volkov AI, Danilova JS, Novozhilova MV, Laaksonen A, Levina OV. Interaction of amines with electrodes modified by polymeric complexes of Ni with salen-type ligands. Electrochim Acta 2016;211:726-734.

[14] Koçak ÇC, Altin A, Aslışen B, Koçak S. Electrochemical Preparation and Characterization of Gold and Platinum Nanoparticles Modified Poly(taurine) Film Electrode and Its Application to Hydrazine Determination. Int J Electrochem Sci 2016;11:233-249.

[15] Silva SM, Aguiar LF, Carvalho RMS, Tanaka AA, Damos FS, Luz RCS. A glassy carbon electrode modified with an iron $\mathrm{N}_{4}$-macrocycle and reduced graphene oxide for voltammetric sensing of dissolved oxygen. Microchimica Acta 2016;183:1251-1259.

[16] Lane RF, Hubbard AT. Electrochemistry of chemisorbed molecules: 2. The influence of charged chemisorbed molecules on the electrodes reactions of platinum electrodes. J Phys Chem 1973;77:1401-1410.

[17] Watkins BF, Behling JR, Kariv E, Miller LL. A Chiral electrode. J Am Chem Soc 1975;97:3549-3550.

[18] Diaz AF, Castillo J, Kanazawa KK, Logan JA. Conducting Poly-N-alkylpyrrole polymer films. J Electroanal Chem 1982;133:233-239. 
[19] Grimshaw J, Perar SD. Redox behaviour of polypyrrole films containing naphthoquinone and benzoquinone groups. J Electroanal Chem 1990;281:125-132.

[20] Haase V, Beck F. Electrodeposition of N-substituted polypyrroles on iron and the CIPL strategy. Electrochim Acta 1994; 39:1195-1205.

[21] Isaacs M, Armijo JF, Ramírez G, Aguirre MJ. Electrochemical reduction of $\mathrm{CO}_{2}$ mediated by poly-M-aminophthalocyanines $(\mathrm{M}=\mathrm{Co}, \quad \mathrm{Ni}, \mathrm{Fe})$ : Poly-Co-tetraaminophthalocyanine, a selective catalyst. J Mol Cata A-Chem 2005;229:249-257.

[22] Grodkowski J, Neta P, Fujita E, Mahammed A, Simkhovich L, Gross Z. Reduction of cobalt and iron corroles and catalyzed reduction of $\mathrm{CO}_{2}$. J Phys Chem A 2002;106:47724778 .

[23] Toma HE, Araki K. Supramolecular assemblies of ruthenium complexes and porphyrins. Coordin Chem Rev 2000;196:307-329.

[24] Elgrishi N, Chambers MB, Wang X, Fontecave M. Molecular polypyridine-based metal complexes as catalysts for the reduction of $\mathrm{CO}_{2}$. Chem Soc Rev 2017;46:761-796.

[25] Lee PK, Nia PM, Woi PM. Facile self-assembled Prussian blue-polypyrrole nanocomposites on glassy carbon: Comparative synthesis methods and its electrocatalytic reduction towards $\mathrm{H}_{2} \mathrm{O}_{2}$. Electrochim Acta 2017;246:841-852. 
[26] Feng X, Zhang K, Hempenius MA, Vancso GJ. Organometallic polymers for electrode decoration in sensing applications. RSC Adv 2015;5:106355-106376.

[27] Choudhary M, Ul Islam R, Witcomb MJ, Mallick K. In situ generation of a highperformance Pd-polypyrrole composite with multi-functional catalytic properties. Dalton Trans 2014;43:6396-6405.

[28] Apetrei C, Rodríguez-Méndez ML, De Saja JA. Amperometric tyrosinase based biosensor using an electropolymerized phosphate-doped polypyrrole film as an immobilization support. Application for detection of phenolic compounds. Electrochim Acta 2011;56:8919-8925.

[29] Hofer E, Steckhan E, Ramos B. Polymer-modified electrodes with pendant $\left[\mathrm{Rh}^{\mathrm{III}}\left(\mathrm{C}_{5} \mathrm{Me}_{5}\right)(\mathrm{L}) \mathrm{Cl}\right]^{+}$complexes formed by $\gamma$-irradiation cross-linking. J Electroanal Chem 1996;402:115-122.

[30] Chang HY, Xu GR, Park Y, Lee KP, Bae ZU. Anionic Polymer-Modified Electrodes Based on a Macrocyclic Nickel(II) Complex for Selective Determination of Dopamine in the Presence of Ascorbic Acid. Bull Korean Chem Soc 2004;25:1261-1264.

[31] Ju H, Gong Y, Zhu H. Electrolyte Effects on Electrochemical Properties of Osmium Complex Polymer Modified Electrodes. Anal Sci 2001;17:59-63. 
[32] Galal A. Electrocatalytic oxidation of some biologically important compounds at conducting polymer electrodes modified by metal complexes. J Solid State Electrochem 1998;2:7-15.

[33] Steter JR, Pontólio JO, Lúcia M, Campos AM, Romero JR. Modified Electrodes Prepared with Polyphenolic Film Containing Ruthenium Complex and Metal Ligand Anchored by Azo Covalent Bond. Braz Chem Soc 2008;19:660-666.

[34] Dahm CE, Peters DG. Catalytic Reduction of Iodoethane and 2-Iodopropane at Carbon Electrodes Coated with Anodically Polymerized Films of Nickel (II) Salen. Anal Chem 1994;66:3117-3123.

[35] Fatibello-Filho O, Dockal ER, Humberto L. Electrochemical Modified Electrodes Based on Metal-Salen Complexes. Anal Lett 2007;40:1825-1852.

[36] Losada J, Del Peso I, Beyer L. Electrochemical and spectroelectrochemical properties of copper (II) Schiff-base complexes. Inorg Chim Acta 2001;321:107-115.

[37] Ourari A, Aggoun D, Ouahab L. A novel copper(II)-Schiff base complex containing pyrrole ring: Synthesis, characterization and its modified electrodes applied in oxidation of aliphatic alcohols. Inorg Chem Commun 2013;33:118-124.

[38] Ourari A, Aggoun D. Synthesis and spectral analysis of N-substituted pyrrole salicylaldehyde derivatives-electropolymerization of a new nickel(II)-Schiff base complex 
derived from 6-[3'-N-pyrrolpropoxy]-2-hydroxyacetophenone and 1,2-diaminoethane. J Iran Chem Soc 2015;12:1893-1904.

[39] Qin H, Gong T, Cho Y, Lee C, Kim T. A conductive copolymer of graphene oxide/poly(1-(3-aminopropyl)pyrrole) and the adsorption of metal ions. Polym Chem $2014 ; 5: 4466-4473$.

[40] Lundrigan T, Jackson CLM, Uddin MdI, Tucker LA, Ali, Al-Sheikh Ali A, Linden A, Cameron TS, Thompson A. Synthesis of heteroleptic pyrrolide/bipyridylcomplexes of ruthenium(II). Can J Chem 2012;90:693-700.

[41] Swami BL, Ikram S. Synthesis of a new Schiff-base complex based on $\mathrm{Cu}$ and its inference in PVC-based membrane as an electroactive material. Asia-Pac J Chem Eng $2015 ; 10: 369-376$.

[42] Trujillo A, Justaud F, Toupet F, Cador O, Carrillo D, Manzur C, Hamon JR. New copper (II)-centered complexes with organometallic donor-acceptor substituted unsymmetrical Schiff base ligands. New J Chem 2011;35:2027-2036.

[43] Franco E, Lopez-Torres E, Mendiola MA, Sevilla MT. Synthesis, spectroscopic and cyclic voltammetry studies of copper II complexes with open chain, cyclic and a new macrocyclic thiosemicarbazones, Polyhedron 2000:19:441-451. 
[44] Valdes-Martinez J, Toscano RA, Zentella-Dehesa A. Synthesis, crystal and molecular structure of 5-bromo-salicylaldehyde-2-methylthiosemicarbazonato- (nitrato)-copper(ii) monohydrate. Polyhedron 1996;15:427-431.

[45] Wiles AB, Bozzuto D, Cahill CL, Pike RD. Copper (I) and (II) complexes of melamine. Polyhedron 2006;25:776-782.

[46] Naskar S, Naskar S, Mayer-Figge H, Sheldrick WS, Chattopadhyay SK. Synthesis, X-ray crystal structures, spectroscopic and cyclic voltammetric studies of $\mathrm{Cu}(\mathrm{II})$ Schiff base complexes of pyridoxal. Polyhedron 2011;30:529-534.

[47] Martins M, Vilas-Boas M, De Castro B, Hillman AR, Freire C. Spectroelectrochemical characterisation of copper salen-based polymer-modified electrodes. Electrochimica Acta $2005 ; 51: 304-314$.

[48] Villalba M, Del Pozo M, Calvo EJ. Alkaloid induced enantioselective electroreduction of acetophenone. Electrochimica Acta 2015;16:125-131.

[49] Vago M, Tagliazucchi M, Williams FJ, Calvo EJ. Electrodeposition of a palladium nanocatalyst by ion confinement in polyelectrolyte multilayers. Chem Commun 2008;57465748.

[50] Feroci M, Orsini M, Palombi L, Sotgiu G, Franco ME, Lopez-Torres E, Mendiola MA, Sevilla MT. Synthesis, spectroscopic and cyclic voltammetry studies of copper II complexes with open chain, cyclic and a new macrocyclic thiosemicarbazones. J Org Chem 2004;69:487. 
[51] Chen BL, Xiao Y, Xu XM, Yang HP, Wang H, Lu JX.Alkaloid induced enantioselective electroreduction of acetophenone. Electrochimica Acta 2013;107:320-326

[52] Kashimura S, Murai Y, Tamai Y, Hirose R, Ishifune M, Iwase H, Yamashita H, Yamashita N, Kakegawa H. Preparation of novel modified electrode by anodic oxidation of carbon fiber with radical $\mathrm{NO}_{3}$ and its application to the selective reduction of acetophenone, Electrochimica Acta 2001;46:3265-3268.

[53] Maiorova NA, Stepanov AA, Grachev MK, Kurochkina GI, Grinberg VA. Electrochemical Hydrogenation of Acetophenone and Methyl-4-isobutylacetophenone in a Two-phase Water-Organic System Containing $\beta$-Cyclodextrin. Russ J Electrochem 2004;40:1074-1078.

[54] Savéant JM. Molecular Catalysis of Electrochemical Reactions. Mechanistic Aspects. Chem Rev 2008;108:2348-2378.

[55] Ciucu AA. Chemically Modified Electrodes in Biosensing. J Biosens Bioelectron 2014;5:1000154.

[56] Zagal J.H, Bediou F, Dodelet JP. N $\mathrm{N}_{4}$-Macrocyclic Metal Complexes, Springer Science, New York 2006;363-438. 
[57] Isaacs M, Canales JC, Aguirre MJ, Etiu G, Caruso F, Ferraudi G. Costamagna J. Electrocatalytic reduction of $\mathrm{CO}_{2}$ by aza-macrocyclic complexes of $\mathrm{Ni}(\mathrm{II}), \mathrm{Co}(\mathrm{II})$, and $\mathrm{Cu}(\mathrm{II})$. Theoretical contribution to probable mechanisms. Inorganic Chimica Acta 2002;339:224-232.

[58] Costamagna J, Ferraudi G, Canales J, Vargas J. Carbon dioxide activation by azamacrocyclic complexes. Coordin Chem Rev 1996;148:221-248.

[59] Losada J, Del Peso I, Beyer L. Redox and electrocatalytic properties of electrodes modified by films of polypyrrole nickel(II) Schiff-base complexes. J Electroanal Chem 1998;447: 147-154. 